Review

\title{
A Small Protein but with Diverse Roles: A Review of EsxA in Mycobacterium-Host Interaction
}

\author{
Yanqing Bao, Lin Wang and Jianjun Sun * \\ Department of Biological Sciences, Border Biomedical Research Center, University of Texas at El Paso, \\ 500 West University Avenue, El Paso, TX 79968, USA; ybao@utep.edu (Y.B.); lwang4@utep.edu (L.W.) \\ * Correspondence: jsun@utep.edu
}

check for updates

Citation: Bao, Y.; Wang, L.; Sun, J. A Small Protein but with Diverse Roles: A Review of EsxA in Mycobacterium-Host Interaction. Cells 2021, 10, 1645. https://doi.org/ 10.3390/cells10071645

Academic Editors: Jarosław Dziadek and Jolanta Zakrzewska-Czerwińska

Received: 31 May 2021

Accepted: 28 June 2021

Published: 30 June 2021

Publisher's Note: MDPI stays neutral with regard to jurisdictional claims in published maps and institutional affiliations.

Copyright: (c) 2021 by the authors. Licensee MDPI, Basel, Switzerland. This article is an open access article distributed under the terms and conditions of the Creative Commons Attribution (CC BY) license (https:/ / creativecommons.org/licenses/by/ $4.0 /)$.

\begin{abstract}
As a major effector of the ESX-1 secretion system, EsxA is essential for the virulence of pathogenic mycobacteria, such as Mycobacterium tuberculosis (Mtb) and Mycobacterium marinum (Mm). EsxA possesses an acidic $\mathrm{pH}$-dependent membrane permeabilizing activity and plays an essential role by mediating mycobacterial escape from the phagosome and translocation to the cytosol for intracellular replication. Moreover, EsxA regulates host immune responses as a potent T-cell antigen and a strong immunoregulator. EsxA interacts with multiple cellular proteins and stimulates several signal pathways, such as necrosis, apoptosis, autophagy, and antigen presentation. Interestingly, there is a co-dependency in the expression and secretion of EsxA and other mycobacterial factors, which greatly increases the complexity of dissecting the precise roles of EsxA and other factors in mycobacteriumhost interaction. In this review, we summarize the current understandings of the roles and functions of EsxA in mycobacterial infection and discuss the challenges and future directions.
\end{abstract}

Keywords: Mycobacterium tuberculosis; EsxA; membrane-permeabilizing activity; immunoregulator; host-pathogen interaction

\section{Introduction}

Mycobacterium is a genus that consists of at least 188 different species [1-4]. Several of them, especially Mycobacterium tuberculosis (Mtb), are imposing a great threat to public health due to their strong virulence and pathogenicity to humans [5-12]. As the causative pathogen of tuberculosis disease (TB), Mtb infects around one-third of the world population and causes 1.4 million deaths each year worldwide [13]. The global TB epidemic is largely attributed to the ability of Mtb to invade and stay persistent in host cells [14-19]. Hundreds of genes necessary for Mtb intracellular survival have been identified [6,20-25]. Among these genes, EsxA (6 kDa early secreted antigenic target, ESAT-6) and EsxB (10 kDa culture filtrate protein, CFP-10) have drawn much attention for their essential roles in Mtb virulence [26-29]. The es $x B A$ operon is located within the es $x-1$ locus that encodes the ESX-1 Type VII secretion system [30-33]. Both EsxA and EsxB are found in the Mtb culture supernatant and considered as the secreted substrates of the ESX-1 system [34]. EsxA was first identified as a potent T-cell antigen [35,36]. Therefore, it has become a major target of new vaccine development against Mtb [37-40]. EsxA is upregulated during Mtb infection [41], and gene deletion or the impaired secretion of EsxA leads to reduction in Mtb intracellular survival [28-30,42], which implicates EsxA as playing an essential role in Mtb virulence. EsxA mediates mycobacterial escape from the phagosome and translocation to the cytosol (here termed cytosolic translocation) through its acidic-pHdependent membrane-permeabilizing activity (MPA) that disrupts lipid membranes at low pH (Figure 1) [43-52]. Interestingly, other mycobacterial factors are also involved in mycobacterial cytosolic translocation, and the co-dependent expression and secretion of EsxA with other factors increases the complexity of dissecting the precise roles of EsxA in mycobacterial pathogenesis [43,53-55]. Moreover, EsxA is a strong immunoregulator and interacts with multiple cellular proteins and signaling pathways $[35,36,40,56-60]$. In 
this review, we summarize the current understandings of the diverse roles of EsxA in mycobacterial pathogenesis and regulation of host immune responses, which is followed by a discussion of the challenges and future directions.
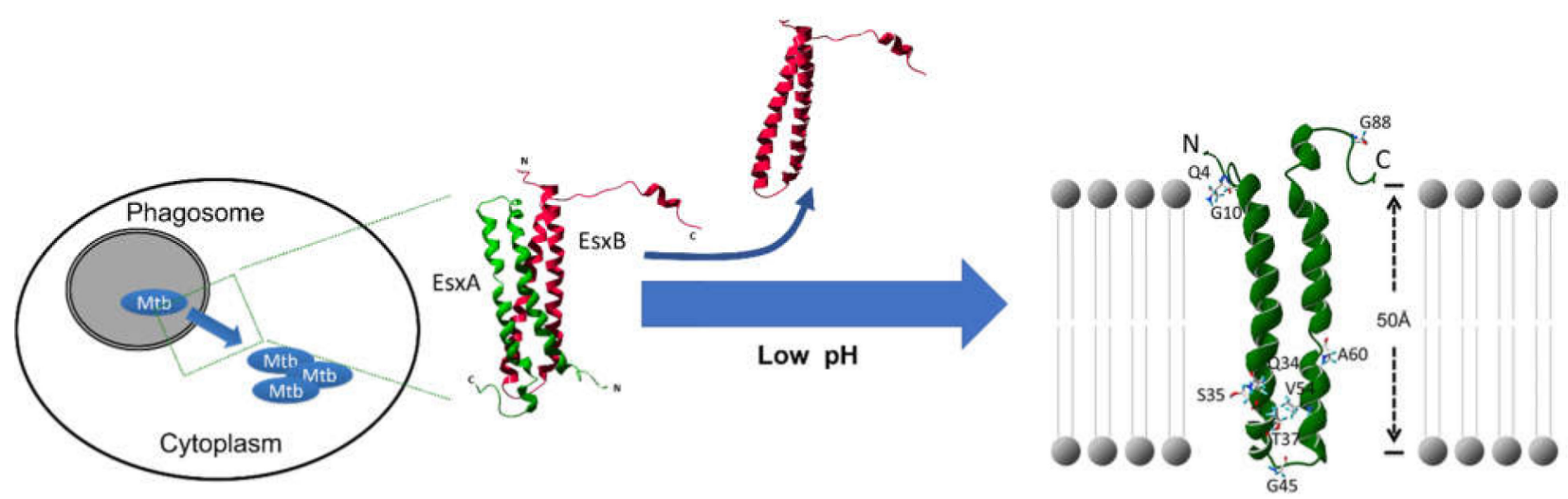

Figure 1. The model of EsxA-mediated Mtb cytosolic translocation. Mtb is internalized into the phagosome of macrophage. Upon acidification, the secreted EsxAB heterodimer is dissociated, and EsxA inserts into the membrane, which facilitates $\mathrm{Mtb}$ escape from the phagosome and translocation into the cytosol for intracellular replication. The figure is modified from [61].

\section{Current Understanding of EsxA's Role in Mycobacterium-Host Interaction}

\subsection{The EsxA MPA Mediates Mycobacterial Cytosolic Translocation}

BCG (Bacillus Calmette-Guérin), an attenuated strain of Mycobacterium bovis, has been used as a TB vaccine for one hundred years. Genomic comparison between Mtb and BCG has found that the region of difference 1 (RD1), which is present in Mtb but absent in BCG, is essential for mycobacterial virulence [28,30,62-66]. RD1 is located in the es $x-1$ locus and includes the esxBA operon. The deletion of RD1/ESX-1 attenuates mycobacterial virulence (e.g., Mtb and Mm) [28,53] and specifically reduces their ability to penetrate the phagosome and translocate into the cytosol for replication and cell-to-cell spreading, which is a major mechanism of mycobacterial virulence (Figure 1) [47,48,52]. Deletion of the es $x B A$ operon or impairment of the secretion of EsxA and/or EsxB cause an equivalent virulence attenuation compared to the deletion of RD1, indicating that EsxA and EsxB are the virulence effectors of the ESX-1 system $[28,43,49,50]$.

Biochemical studies demonstrate that EsxA protein, either purified from Escherichia coli (E. coli) or Mtb culture supernatant, possesses an acidic pH-dependent MPA [46,67]. Although the homologues of EsxA exist across different mycobacterial species [68-70], such activity is only found in the EsxA proteins from pathogenic mycobacteria, such as Mtb and Mm [46], but not from non-pathogenic Mycobacerium smegmatis (Ms), which links the EsxA MPA with mycobacterial virulence. Upon acidification, EsxA undergoes significant conformational changes and disrupts liposome membranes $[46,67]$. The central helix-turnhelix motif of EsxA inserts into the liposome membrane to form a membrane-spanning structure, while the $\mathrm{N}$ - and C-terminal flexible arms hang on the surface of the membrane (Figure 1) [46,61]. Site-directed mutagenesis has found that Gln5 (Q5) is the critical residue for the MPA. Replacing Q5 with a basic residue (e.g., Q5K and Q5R) diminishes the MPA, while replacing it with a hydrophobic residue (e.g., Q5V, Q5I) enhances the MPA. Importantly, the virulence of the $\mathrm{Mtb} / \mathrm{Mm}$ strains carrying the mutations Q5K or Q5V is either attenuated by Q5K or enhanced by Q5V, which establishes a clear link between the EsxA MPA and the ability of mycobacteria to penetrate the phagosome and translocate into the cytosol for replication and cell-to-cell spreading [44]. Most recently, a 13-amino-acid SpyTag (ST) was engineered into the C-terminus of EsxA without significant impact on the expression, secretion, and MPA of EsxA. The EsxA-ST can only be specifically recognized and conjugated by the SpyCatcher (SC)-GFP through the covalent bonding between ST and SC after EsxA-ST is secreted out of mycobacteria. Thus, the SC-GFP binding to EsxA-ST 
only inhibits the EsxA MPA and has no effect on other co-dependently secreted factors. Inhibition of the EsxA-ST MPA at the post-secretion level by SC-GFP significantly reduces the Mm intracellular survival, which confirms the essential role of the EsxA MPA in mycobacterial virulence [71].

The MPA is present in the EsxA protein from pathogenic mycobacteria, such as Mtb and $\mathrm{Mm}$, but absent in the orthologous EsxA protein from non-pathogenic Ms [46,72]. Earlier studies have shown that Ms also has a conserved and functional ESX-1 system that can secrete Mtb EsxA and EsxB [73], and this ESX-1 system is essential for DNA transfer in Ms [74], but the putative role of EsxA in non-pathogenic mycobacteria is not clear.

\subsection{EsxA Disassociates from EsxB to Exhibit MPA}

Esx $A$ and EsxB are expressed from the es $x B A$ operon, form a heterodimer (here termed EsxAB) inside mycobacteria, and secreted out of mycobacteria in a co-dependent manner [27,75-79]. EsxAB exhibits structural changes and biological functions, such as binding to macrophages, regulation of NF- $\mathrm{KB}$ transactivation, and inhibition of autophagy $[27,78,80,81]$. An earlier study with the native EsxA and EsxB proteins isolated from the culture filtrate has proposed a model in which the EsxAB is dissociated upon acidification, allowing EsxA to interact with lipid membranes [67]. However, the recombinant EsxA (rEsxA) purified from E. coli remains binding to EsxB even at a low $\mathrm{pH}$ condition [79]. This has intrigued a hypothesis that the EsxA protein produced in mycobacteria has unique post-translational modifications that are not available in E. coli [82]. Indeed, EsxA produced in mycobacteria is acetylated at the Thr2 residue after Met1 is removed, which is a process called $\mathrm{N}^{\alpha}$-acetylation. Furthermore, EsxB preferably binds to the nonacetylated EsxA than the acetylated EsxA, indicating that $\mathrm{N}^{\alpha}$-acetylation at Thr2 is the key factor facilitating the dissociation of EsxAB at low $\mathrm{pH}[83,84]$. Moreover, the homeostasis of $\mathrm{N}^{\alpha}$-acetylation of EsxA is correlated to the mycobacterial virulence [85]. A recent study with site-directed mutagenesis at Thr2 has obtained direct evidence that the mutations at Thr2, which precludes $\mathrm{N}^{\alpha}$-acetylation, inhibits the heterodimer separation and hence prevents EsxA from interacting with the host membrane, resulting in attenuated mycobacterial cytosolic translocation and virulence. Interestingly, molecular dynamics (MD) simulations have revealed the molecular mechanism underlying the heterodimer dissociation. The MD simulations show that at low $\mathrm{pH}$, the $\mathrm{N}^{\alpha}$-acetylated $\mathrm{Thr} 2$ makes direct and frequent "bind-and-release" contacts with EsxB, which generates a force that pulls EsxB away from EsxA (Figure 2) [86]. $\mathrm{N}^{\alpha}$-acetylation of EsxA at Thr2 is a potential target for anti-TB drug developments. 


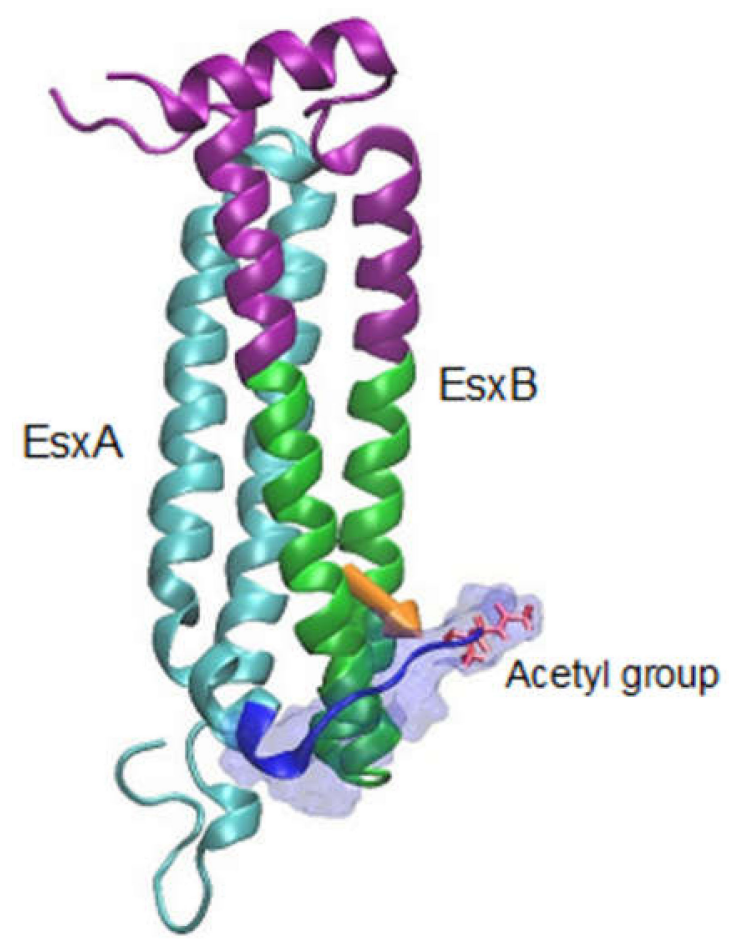

Figure 2. Interaction between the $\mathrm{N}^{\alpha}$-acetylated EsxA and EsxB at $\mathrm{pH}$ 4. The structure of Mtb EsxAB heterodimer with $\mathrm{N}^{\alpha}$-acetylation was analyzed by molecular dynamic simulation. The figure was generated from snapshots of 20 ns molecular dynamic (MD) simulations at pH 4. EsxA is colored in cyan; the N-terminus of EsxA is colored in blue and shown in transparent surface representation. The acetylated Thr-2 residue is shown in bond representation and colored in red. The residues in EsxB within $20 \AA$ of the N-terminus of EsxA are colored in green, and the residues beyond $20 \AA$ are shown in purple. The orange arrows represent the electrostatic interaction between two sets of residues: the residues in the N-terminus of EsxA (blue) and the residues in EsxB within $20 \AA$ of the N-terminus of EsxA (green). The MD simulation shows that the acetylated N-terminal arm of EsxA makes direct contracts with EsxB in a frequent "bind-and-release" mode, which generates a force of $44 \mathrm{pN}$ to pull EsxB away from EsxA. The figure is modified from [86].

\subsection{EsxA Is a Strong Immune Regulator}

As a strong immunoregulator, EsxA interacts with several host proteins and is involved in a number of cellular immune pathways. The purified EsxA binds with the immobilized laminin protein in a dose-dependent manner. Laminin is enriched in the membranes of human alveolar epithelial cells A549 and WI-26 and is believed to mediate the binding between EsxA and the cells [59]. In the airway tract, Mtb entry into epithelial M cells requires a functional ESX-1 system. The beads coated with the purified EsxA efficiently translocate across the $\mathrm{M}$ cell layer, suggesting that EsxA plays a role in mediating Mtb entry into the $\mathrm{M}$ cells. Subsequent co-immunoprecipitation identifies that EsxA interacts with scavenger B-1 in M cells, indicating that scavenger B-1 may function as a surface receptor for EsxA to mediate Mtb invasion in cells and animal models [60].

In macrophages, EsxA and EsxAB bind to beta-2-microglobulin $(\beta 2 \mathrm{M})$ through the C-terminus of EsxA. When incubated with THP-1 cells, EsxA and EsxAB are translocated into endoplasmic reticulum (ER), where $\beta 2 \mathrm{M}$ forms the MHC-I complex. Following the incubation, the cell membrane association of $\beta 2 \mathrm{M}$ and the peptide presentation of MHC-1 are decreased, indicating that EsxA inhibits macrophage antigen presentation by interacting with $\beta 2 \mathrm{M}$ [58]. EsxA binds to the cell surface of RAW264.7 cells in a TLR2-dependent manner. The ELISA assay conducted with the purified EsxA or the EsxA-derived peptides demonstrates that the C-terminus of EsxA directly binds to TLR2 extracellular domain and attenuates the responses of RAW264.7 cell to TLR2 ligand stimulation. Further experiments with inhibitors or genetic silencing have confirmed that PI(3)K and Akt mediate the 
attenuation effect [57]. In murine dendritic cells, EsxA induces a strong production of IL-6 and TGF- $\beta$ in a TLR-2-dependent manner, which directs Th17 differentiation for protective response against $\mathrm{Mtb}$ infection [87].

In addition to interacting with cellular proteins, EsxA stimulates immune responses as a potent T-cell antigen [35,36]. Most epitopes are located in the N-terminus of EsxA, and the residues 51-60 are effectively recognized by T cells [88]. Upon EsxA treatment, the peripheral blood monocyte cells (PBMCs) isolated from the Mtb-infected donors produce significant amounts of cytokines, including IFN- $\gamma$, IL-2, IL-6, IL-8, IL-10, MCP-1, MIP- $1 \alpha$, and TNF- $\alpha$ [35,89-91]. IFN- $\gamma$, IL-2, and TNF- $\alpha$ are mainly produced through Th1 response [92]. IFN- $\gamma$ plays a central role for immunity against Mtb by activating macrophage to kill intracellular Mtb and recruiting immune cells to infection sites [93-96]. Hosts with deficiencies in IFN- $\gamma$ or its corresponding receptor exhibit higher susceptibility and severity to Mtb infection [94,97-99]. As a pro-inflammatory cytokine, TNF- $\alpha$ induces the apoptosis of the alveolar macrophages infected with Mtb, which limits Mtb intracellular survival [100]. It coordinates with IFN- $\gamma$ to induce reactive nitrogen intermediates against Mtb in macrophages [101,102]. By inducing the migration of immune cells to the infection sites, TNF- $\alpha$ is critical for the formation of Mtb-containing granuloma. Inhibition of TNF- $\alpha$ impairs granuloma formation and increases the severity of Mtb infection [103,104]. IL-2 mainly promotes T-cell proliferation to affect the magnitude of immune response [105]. Since the IL-2/IFN- $\gamma$ secretion profile in the T cells infected with either active and or inactive $\mathrm{Mtb}$ is different, it is promising to apply IL-2/IFN- $\gamma$ detection to discriminate active TB patients from healthy or vaccinated people [106-109].

IL-6 and IL-10 are the major immune regulators during Mtb infection. In the acute or early stage of infection, IL- 6 is required for IFN- $\gamma$ production and protective response against Mtb [110,111]. It is also required for Th1 immune responses induced by subunit vaccination with Mtb extraction [112]. In the cultured macrophages, IL-6 is negatively correlated with the activation of IFN activation pathways $[113,114]$. The inhibition of the IL-6 trans-signaling pathway yields therapeutic effects on inflammation caused by Mtb infection without significantly increasing bacterial burden, indicating that IL-6 plays a major role in immune regulation in TB progression [115]. IL-10 was firstly identified as an inhibitor of Th1 cell cytokines [116]. During Mtb infection, IL-10 inhibits the production of pro-inflammatory cytokines, which are responsible for macrophage antigen presentation. Thus, the subsequent T-cell activation is inhibited by IL-10 [117]. Deficiency in IL-10 enhances immune responses against $\mathrm{Mtb}$ infection and reduces the bacterial burden in mouse lung [118]. For innate killing against Mtb, IL-10 blocks maturation of the Mtbcontaining phagosomes and enhances Mtb intracellular survival in macrophages [119]. In the Mtb-infected macrophages, IL-10 counteracts the TNF- $\alpha$-induced apoptosis and reduces nitric oxide production as well as caspase-1 activation [120].

IL-8, MCP-1, and MIP-1 $\alpha$ are chemokines responsible for cell migration and granuloma formation, which are parts of immune responses induced by Mtb infection [121-124]. During Mtb infection, IL-8 is secreted by alveolar macrophages, peripheral blood lymphocytes, and alveolar epithelial cells upon Mtb infection [125-127]. It mainly stimulates the migration of neutrophils and lymphocytes during Mtb infection [128,129]. IL-8 is significantly upregulated in the infected-tissue fluid and the neutrophil-infiltrated granuloma in TB patients [129-131]. The neutralization of IL-8 reduces granuloma formation in animal models [132]. MCP-1 is secreted by macrophages upon Mtb infection or TNF- $\alpha$ stimulation $[133,134]$. Similar to IL-8, the production of MCP-1 is significantly upregulated in pleural effusion of TB patients [129], and it increases macrophage recruitment to lung [135]. MCP-1 also functions as an inhibitor of the immune responses against Mtb. Genetic studies demonstrate that populations with certain MCP-1 gene mutations produce high concentrations of MCP-1, which inhibits IL-12p40-mediated immune responses against Mtb [136]. MIP- $1 \alpha$ is secreted by neutrophils and macrophages upon Mtb infection $[129,137]$. Similar to $\mathrm{MCP}-1, \mathrm{MIP}-1 \alpha$ is partially dependent on TNF- $\alpha$ stimulation [138]. In coordination with 
MCP-1, MIP-1 $\alpha$ mediates the migration of neutrophils to granuloma [139]. It also stimulates Th1 response by driving T-cell differentiation and enhancing IFN- $\gamma$ secretion $[140,141]$.

In recent years, EsxA has also been found to modulate host immune responses by regulating host microRNAs (miRNA). By repressing miRNA let-7 in an EsxA-dependent manner, $\mathrm{Mtb}$ upregulates the expression of A20, an NF- $\mathrm{KB}$ inhibitor, and inhibits macrophage function, which significantly upregulates Mtb survival [142]. EsxA upregulates the miRNA155 transcription in macrophages, which inhibits the production of cyclooxygenase-2 and IL-2, hence upregulating apoptosis $[143,144]$. The upregulation of miRNA155 inhibits autophagy, which favors Mtb survival in mouse macrophages and human dendritic cells [143,145]. Either the purified EsxA or Mm infection downregulate miR-148 or miR-147 in mouse macrophages, which increases Mm intracellular survival, suggesting that EsxA increases Mm intracellular survival by inhibiting the two miRNAs [146,147].

\subsection{EsxA-Mediated Cytotoxic Effects: Necrosis and Apoptosis}

Mtb infection of macrophages leads to both necrosis and apoptosis [148-150], while Mtb infection of lung epithelial cells and neutrophils mainly leads to necrosis [151-154]. The mycobacterial strains without EsxA cause significantly lower cell death $[49,155]$, suggesting that EsxA is essential for the cytotoxic effects.

Purified EsxA induces intracellular $\mathrm{Ca}^{2+}$ overload to activate calpain-dependent necrosis in aged neutrophils, which might be related to EsxA interaction with the externalized phosphatidylserine on neutrophil cell surface [153]. Mycobacterial infection upregulates macrophage necrosis and the secretion of IL-1 $\beta$ and IL-18 through the activation of inflammasome pathways $[56,150,156-158]$. The studies with genetic silencing methods further identified that EsxA activates the NLRP3/ASC complex [56,157]. By causing phagosome or lysosome leakage, EsxA induces the release of cathepsin B into the cytosol to activate NLRP3/ASC, which is critical for macrophage necrosis [158,159]. In lung epithelial cells, EsxA-mediated necrosis is closely related to mycobacterial virulence [151,155]. EsxA increases mycobacterial intracellular replication, which overwhelms lung epithelial cells by increased membrane permeation and necrosis [71,151,160]. In the epithelial cells incubated with EsxA, necrosis is upregulated through the activation of MAPK and ERK pathways [161].

The effects of EsxA on apoptosis have been widely studied. EsxA protein induces apoptosis in both epithelial and macrophage cells through various pathways. Incubation with the purified EsxA protein, but not other Mtb proteins, induces apoptosis in THP-1 cells, which is blocked by anti-EsxA antibody [162]. Since the transcription of caspase-1, -3 , $-5,-7,-8$, and -9 are upregulated, it strongly indicates that EsxA induces apoptosis through caspase pathways [162,163]. As a regulator of ER stress response, BAT3 inhibits the EsxAinduced macrophage apoptosis, indicating that EsxA also mediates apoptosis through the ER stress response pathway [164]. In lung epithelial cells, EsxA induces apoptosis by upregulating the expression of caspase-3, -4 , and -12 through the ER stress response [165]. The EsxA protein also regulates caspase-3 activation through the miR-155-SOCS1 pathway for apoptosis [144]. In infection assays, Mtb, but not the mutant strain without EsxA, upregulates Bcl-2-interacting mediator and induces macrophage apoptosis in vitro [166]. In vivo, Mtb induces macrophage apoptosis in granuloma, while the $\triangle$ RD1 strain exhibits a significantly lower ability to induce apoptosis [167]. All these studies have demonstrated that EsxA plays an essential role in host cell apoptosis.

\subsection{Effects of EsxA on Autophagy}

Autophagy is a fundamental cellular function to maintain the homeostasis of the intracellular environment [168], including the removal of intracellular pathogens [169]. When mycobacteria gain access to the cytosol, the rupture of mycobacteria-containing vacuole triggers the STING pathway to induce autophagy [170,171]. Followed by enhanced fusion with lysosome, autophagy selectively degrades mycobacteria to inhibit its intracellular survival [172,173]. As a Mtb virulence effectors, EsxA counteracts autophagy with 
various mechanisms. The mutant strain without EsxA fails to inhibit the fusion between autophagosome and lysosome in dendritic cells, implicating EsxA as playing an essential role in autophagic flux [174]. Further study with the ectopically expressed EsxA demonstrates that by upregulating mTOR activity, a negative regulator of autophagy [175], EsxA inhibits autophagy flux and protein degradation in the autophagosome and enhances the intracellular survival of BCG in macrophages [176]. Mass spectrometry analysis shows that both the ectopic expression of EsxA and incubation of the purified EsxA protein upregulate SOD-2 expression in macrophages. Infection of the BCG strain complemented with EsxA also upregulates SOD-2. The knockdown of SOD-2 promotes autophagy and mycobacterial co-localization with lysosomes, resulting in the downregulation of mycobacterial intracellular survival [177]. The protein extract from Mtb culture filtrate also inhibits autophagy, and EsxA purified from extract inhibits autophagy through the upregulation of miR-30a-3p and downregulation of miR-30a-5p. Reverse miRNA transcription recovers autophagy and inhibits mycobacterial intracellular survival, demonstrating the miRNAs' roles in EsxA inhibition on autophagy [178]. Moreover, when co-expressed with EsxB, EsxA still inhibits autophagy and enhances Mtb intracellular survival [80].

\section{The Questions that Remain to Be Answered}

While EsxA has been extensively studied for the past 20 years, its roles in Mtb pathogenesis and host immune regulation are still not completely understood. Recent studies have aroused more questions that need to be addressed. For instance, although EsxA is a strong T-cell antigen, the high expression profile of EsxA during Mtb infection does not always guarantee an effective Th1 immune response. The well-established role of EsxA MPA in mycobacterial cytosolic translocation is also being challenged, which we believe is much related to genetic knockout of the es $x B A$ operon that might have introduced artifacts on the expression or secretion of other co-dependent effectors, resulting in artificial phenotypic changes on mycobacteria.

\subsection{What Is the Mechanism Underlying the Dual Role of EsxA in Immunoregulation?}

As a major antigen, EsxA effectively stimulates Th1 type responses. Combined with proper adjuvants, EsxA induces both strong Th1 and humoral responses and provides comparable protection as the BCG vaccine in animal models [37]. The epitope Esx $A_{51-70}$ induces effective protection against Mtb challenge [179]. When combined with Ag85b, another Mtb immunodominant antigen [180], EsxA vaccination induces even a longer protection effect in mouse lung than BCG (30). The recombinant BCG strain that secretes EsxA provides a much better protection than BCG in animal models [39].

Interestingly, however, EsxA might also contribute to protection failure. Although Mtb antigens specifically induce immune responses, hosts can only limit the infection instead of eradication [181,182], which indicates a possibility that Mtb limits T-cell responses during infection. Later, it has been found that Mtb downregulates and "hides" Ag85b expression during infection, resulting in a significant decrease of activated T cells [183]. Unlike Ag85b, EsxA expression and T-cell recognition are sustained throughout the infection, leading to more differentiated EsxA-specific T cells [184-186]. However, the activated T cells fail to secrete cytokines and proliferate, which is probably attributed to exhaustion by constant antigen stimulation [40]. Repeat injections of EsxA subunit vaccine in short intervals cause weaker immune responses and protection, supporting that the constant stimulation of EsxA inhibits host immunity against Mtb [40].

\subsection{Is Low pH Required for Mycobacterial Cytosolic Translocation?}

Biochemical studies have demonstrated that at $\mathrm{pH} 5$ or lower, EsxA undergoes conformational changes and inserts into the liposomal membranes, which is not observed in the EsxA protein from Ms $[46,61]$, indicating that the low $\mathrm{pH}$-dependent MPA is a determinant factor for mycobacterial virulence. The point mutations at Q5 (e.g., Q5K and Q5V) either upregulate or downregulate the low $\mathrm{pH}$-dependent MPA in liposomes and accordingly up- 
regulate or downregulate mycobacterial virulence in cultured macrophages and zebrafish, which has established an unambiguous link between the low $\mathrm{pH}$-dependent MPA and mycobacterial virulence [44]. Most recently, the MPA of EsxA-ST is inhibited by GFP-SC through the specific ST-SC covalent bonding in the liposome assay, and accordingly, the intracellular survival of the Mm(EsxA-ST) is inhibited by the overexpression of GFP-SC in the cultured cells [71]. All the evidence above has established a solid link between the low $\mathrm{pH}$-dependent MPA of EsxA and mycobacterial virulence in infection.

However, numerous studies report that EsxA disrupts lipid membranes at neutral $\mathrm{pH}$. Earlier, either EsxA alone or with EsxB disrupted the lipid bilayer at neutral $\mathrm{pH}$ [28]. The purified EsxA or EsxAB exhibited cytolytic activity on human lung epithelial cells and caused cell death [59]. Now, it has become clear that the EsxA-mediated cytolysis at neutral $\mathrm{pH}$ is attributed to the residual detergent used in protein purification [53]. The purified EsxA exhibits membrane disruption activity only when it is treated with ASB-14, which is a zwitterionic detergent for endotoxin removal [53]. This protocol had been used in several studies $[28,50,187]$. Our recent data show that even after several detergent removal procedures, the concentration of the residual ASB-14 in the purified EsxA still ranges from 12 to $32 \mu \mathrm{g} / \mathrm{mL}$, which is enough to cause cell lysis [188]. In fact, instead of causing cytolysis, the exogenously added EsxA protein without ASB-14 is internalized into the lung epithelial cells and traffics to acidic subcellular compartments, where it inserts into the membranes [188]. These results deny the possibility that EsxA permeabilizes lipid membranes at neutral $\mathrm{pH}$.

Sheep red blood cells (RBCs) have been used to evaluate EsxA or mycobacteriamediated hemolytic activity. Incubation with the purified EsxA or mycobacteria induces hemolysis, while the deletion of the EsxA or ESX-1 system greatly reduces hemolysis. A transmission electron micrograph shows that Mm disrupts the RBC membranes in a contact-dependent manner $[50,53,187,189]$. While mycobacteria induce RBC cytolysis in vitro, no report indicates that pathogenic mycobacteria cause tuberculosis by lysing $\mathrm{RBC}$ in vivo. Thus, the observed $\mathrm{RBC}$ hemolysis might be an in vitro artifact. The RBC membrane consists of $\approx 40 \%$ lipids and $52 \%$ of proteins [190,191], which is not equivalent to the membranes used in the liposome and phagosome. Our recent data indicate that the fluidity and net charge of fatty acids have a significant influence on EsxA interaction with the membranes [192]. In the sheep RBC membrane, phosphatidylethanolamine (PE) makes up more than $30 \%$ of the membrane phospholipids [193] and confers a much higher membrane fluidity [194]. Thus, it would not be surprising that EsxA had a much higher MPA toward this membrane, even at neutral $\mathrm{pH}$ [192]. Considering that proteins make up around $52 \%$ of the RBC membrane and mycobacteria-mediated hemolysis depends on direct contact with RBC [190], the possibility that mycobacteria interact with RBC membrane proteins to induce membrane rupture cannot be overlooked.

A recent study has shown that mycobacteria are still able to escape from the phagosome in the presence of bafilomycin, which is a reagent inhibiting acidification [53]. However, there are three major concerns regarding the data. One, while the lysotracker is generally used as an intracellular $\mathrm{pH}$ indicator, it is not for accurate and quantitative $\mathrm{pH}$ measurement. It is possible that acidification was partially inhibited, but the $\mathrm{pH}$ was still low enough for EsxA to permeabilize phagosomes. Second, in the report, the rate of phagosome permeabilization for MmWT was only $\approx 6 \%$, which only represents a small population of the bacteria. Third, bafilomycin appeared to enhance the permeabilization rate of $\mathrm{Mm} \triangle \mathrm{RD} 1$ (from $0.82 \%$ to $3.2 \%$ ), but not MmWT, suggesting that bafilomycin treatment could generate unexpected artifacts to mislead the results. In fact, it has been reported that the treatment of bafilomycin not only inhibits phagosome acidification, but it also alters phagosome membrane composition [195], which is critical for the function of intracellular pathogen-secreted effectors [196,197]. Given that the EsxA MPA is also affected by membrane composition [192], it is possible that bafilomycin treatment affects the membrane composition, which allows mycobacteria to escape from the phagosome even when acidification is inhibited. 


\subsection{Is EsxA Required for Mycobacterial Cytosolic Translocation?}

Genetic studies using the strains with the deletion or disruption of es $x A$ or es $x B A$ have shown that EsxA is required for mycobacterial virulence $[44,50,53,77,86]$. However, a recent study has shown that the transposon mutants, which are defected in EsxAB secretion, are still able to escape from the phagosome, indicating that factors other than EsxA are required for mycobacterial cytosolic translocation and virulence [43]. The major concern for this report is that the gene deletion caused by transposon insertion might induce a genetic compensatory mechanism in mycobacteria and produce artifacts. Moreover, it has been shown that the expression and secretion of EsxAB as well as numerous factors encoded within or outside the ESX-1 locus are co-dependent on each other [42,43,54,55,75,198-200]. For instance, the deletion of esxA blocks the secretion of EspA in Mtb [75]. In Mm, the deletion of es $x A$ or es $x B A$ reduces the expression and secretion of EspB and EspF as well as EsxN encoded within the ESX-5 locus, but it upregulates the secretion of MMAR_2929 from the Sec system [54]. Moreover, the disruption of other ESX-1 genes alters the expression or secretion of EsxA. The deletion of espE or espF significantly upregulates the expression and secretion of EsxA but downregulates hemolysis [55]. The co-dependency among EsxAB and various effectors is summarized in Table $1[54,55,75]$, which greatly increases the complexity of dissecting the roles of each individual factor in mycobacterial pathogenesis. Considering the co-dependency complexity, the results obtained by gene deletion and disruption need to be carefully interpreted.

Table 1. Expression and secretion co-dependence among ESX-1 effectors.

\begin{tabular}{|c|c|c|c|c|c|}
\hline \multicolumn{3}{|c|}{ Effect of EsxA's Deletion on Other Effectors } & \multicolumn{3}{|c|}{ Effect of Other Effectors's Deletion on EsxA } \\
\hline$\Delta$ EsxA (48) & $C L^{a}$ & $C^{b}$ & EsxA & $C L^{a}$ & $\mathrm{CF}^{\mathrm{b}}$ \\
\hline EsxB & $\downarrow$ & $\downarrow$ & $\Delta$ EsxB [54] & $\downarrow$ & $\downarrow$ \\
\hline EspB & $\downarrow$ & $\downarrow$ & $\Delta \mathrm{EspB}[54]$ & $\downarrow$ & $\downarrow$ \\
\hline EspF & $\downarrow$ & $\downarrow$ & $\Delta \operatorname{EspE}[55]$ & $\uparrow$ & $\uparrow$ \\
\hline EspK & $\downarrow$ & $\downarrow$ & $\Delta$ EspF [55] & $\uparrow$ & $\uparrow$ \\
\hline EspJ & $\uparrow$ & $\downarrow$ & $\Delta$ EspK [54] & - & $\downarrow$ \\
\hline \multirow[t]{4}{*}{ PPE68 } & $\downarrow$ & $\downarrow$ & $\Delta$ EspJ [54] & - & $\downarrow$ \\
\hline & & & $\Delta$ EspI [43] & $\downarrow$ & $\downarrow$ \\
\hline & & & $\Delta$ EspG1 [43] & $\downarrow$ & $\downarrow$ \\
\hline & & & $\Delta \mathrm{EspH}[43]$ & $\downarrow$ & $\downarrow$ \\
\hline
\end{tabular}

${ }^{\mathrm{a}}$ : cell lysate; ${ }^{\mathrm{b}}$ : culture filtrate; $\downarrow$ : downregulation; $\uparrow:$ upregulation; -: unaffected.

Three lines of evidence obtained by the approaches other than gene deletion strongly support the essential role of EsxA MPA in mycobacterial cytosolic translocation. First, the point mutations at the residue Q5, which do not affect the expression and secretion of EsxA, hence presumably do not affect other co-dependent factors, upregulate or downregulate the EsxA MPA, and accordingly upregulate or downregulate the mycobacterial cytosolic translocation and virulence [44]. Second, an inducible knockdown of EsxAB at the posttranslational level through a DAS4 degradation tag that is engineered to the C-terminus of EsxB results in attenuated mycobacterial virulence [71]. Third, the Mm(EsxA-ST) strain has a normal expression and secretion of EsxA-ST, but its virulence is attenuated by the overexpression of GFP-SC in the infected host cells, suggesting that EsxA-ST MPA is inhibited by GFP-SC at the post-secretion level, where other co-dependent factors are not likely to be affected [71].

\section{Future Directions}

Current studies suggest that EsxA is necessary but not sufficient for mycobacterial phagosome rupture and cytosolic translocation solely; other factors may also contribute to this process. It has been reported that EsxA works with phthiocerol dimycocerosates (PDIM) to mediate phagosome rupture [201,202], and PDIM alone can cause a certain level of hemolysis with Mm [203]. The disruption of other ESX-1 substrates also impacts 
mycobacterial phagosome escape $[43,53]$. A recent study has reported that the deletion of espE/F significantly inhibits Mm-mediated hemolysis, while the expression and secretion of EsxAB were not affected [55], indicating that Esx $A B$ is not sufficient for mycobacterial virulence. Future studies on the other factors that are involved in mycobacterial cytosolic translocation are needed.

An earlier study has shown that the Mtb without ESX-1 locus exhibits a stronger association with lung epithelial cells, indicating that EsxA plays a role in cell invasion [28]. The Mm strain with the deletion of esxBA has an increased adherence to the murine macrophages [44]. Most recently, our preliminary data have shown that the Mm strain with EsxA deletion has an increased adherence but a decreased invasion in WI-26 [188]. Recent studies have shown that the secreted EsxAB remains associated with the mycobacterial cell wall, rather than released into the medium, and the cell wall-associated EsxAB correlates with bacterial virulence $[85,198,204]$. Thus, it is possible that EsxAB mediates the mycobacterial adherence and invasion into host cells, which implicates a new role of EsxAB in mycobacterial pathogenesis.

Upon acidification, EsxA inserts into the liposomal membrane and forms a transmembrane structure [61], and the exogenously added EsxA with a NBD label is internalized into the lung epithelial cells and inserts into the host membranes within the acidic subcellular compartment [188]. Most recently, molecular dynamic simulation shows that EsxA inserts into lipid membranes in the form of a C4 oligomer [205]. Thus, current studies support that EsxA forms a pore or channel across the lipid membrane. However, the structure of the putative EsxA pore is still not available; hence, its exact function is unknown, which warrants further investigations in the future.

Current studies have shown that EsxA, but not EsxB, possesses the acidic $\mathrm{pH}$-dependent MPA, which is essential for phagosome rupture $[46,67]$. EsxA alone has a Tm at $37^{\circ} \mathrm{C}$ and the heterodimer has a Tm at $55^{\circ} \mathrm{C}$, suggesting that EsxB stabilizes EsxA at $37^{\circ} \mathrm{C}$ [206]. EsxA and EsxB are secreted through the ESX-1 system as a heterodimer [75], and the C-terminal $Y x x D / E$ motif of EsxB is required for the secretion [207]. The evidence above supports that EsxB functions as a chaperone of EsxA for its secretion and stabilization. However, in addition to functioning as a chaperon, EsxB has been shown to be responsible for triggering $\mathrm{Ca}^{2+}$ response in human neutrophils in a pertussis toxin-sensitive manner, suggesting that EsxB contributes specifically to neutrophil recruitment and activation during Mtb infection [208]. Therefore, for a more complete picture of ESX-1 effectors' roles, the roles of EsxB need more investigation. Moreover, due to the mutual codependence among ESX-1 effectors, a study of EsxB without having impact on other ESX-1 effectors needs to be carefully considered.

Author Contributions: Y.B., L.W. and J.S. wrote the manuscript. All authors have read and agreed to the published version of the manuscript.

Funding: The research is funded by a grant from NIGMS (SC1 GM095475 to J. Sun).

Acknowledgments: The study is supported by the grants from NIGMS(SC1GM095475 to J.S.). The content is solely the responsibility of the authors and does not necessarily represent the official views of the National Institutes of Health.

Conflicts of Interest: The authors declare no conflict of interests.

\section{References}

1. Barksdale, L.; Kim, K.-S. Mycobacterium. Bacteriol. Rev. 1977, 41, 217. [CrossRef] [PubMed]

2. Tortoli, E. Microbiological features and clinical relevance of new species of the genus Mycobacterium. Clin. Microbiol. Rev. 2014, 27, 727-752. [CrossRef]

3. Pfyffer, G.E. Mycobacterium: General characteristics, laboratory detection, and staining procedures. Man. Clin. Microbiol. 2015, 536-569.

4. Gupta, R.S.; Lo, B.; Son, J. Phylogenomics and comparative genomic studies robustly support division of the genus Mycobacterium into an emended genus Mycobacterium and four novel genera. Front. Microbiol. 2018, 9, 67. [CrossRef] 
5. Glickman, M.S.; Jacobs, W.R. Microbial pathogenesis of Mycobacterium tuberculosis: Dawn of a discipline. Cell 2001, $104,477-485$. [CrossRef]

6. Meena, L.S. Survival mechanisms of pathogenic Mycobacterium tuberculosis H37Rv. FEBS J. 2010, 277, 2416-2427. [CrossRef] [PubMed]

7. Van der Werf, T.S.; Stienstra, Y.; Johnson, R.C.; Phillips, R.; Adjei, O.; Fleischer, B.; Wansbrough-Jones, M.H.; Johnson, P.D.; Portaels, F.; van der Graaf, W.T. Mycobacterium ulcerans disease. Bull. World Health Organ. 2005, 83, 785-791. [PubMed]

8. Schuenemann, V.J.; Singh, P.; Mendum, T.A.; Krause-Kyora, B.; Jäger, G.; Bos, K.I.; Herbig, A.; Economou, C.; Benjak, A.; Busso, P. Genome-wide comparison of medieval and modern Mycobacterium leprae. Science 2013, 341, 179-183. [CrossRef] [PubMed]

9. Van Der Sar, A.M.; Abdallah, A.M.; Sparrius, M.; Reinders, E.; Vandenbroucke-Grauls, C.M.; Bitter, W. Mycobacterium marinum strains can be divided into two distinct types based on genetic diversity and virulence. Infect. Immun. 2004, 72, 6306-6312. [CrossRef] [PubMed]

10. Alcaide, F.; Richter, I.; Bernasconi, C.; Springer, B.; Hagenau, C.; Schulze-Röbbecke, R.; Tortoli, E.; Martín, R.; Böttger, E.C.; Telenti, A. Heterogeneity and clonality among isolates of Mycobacterium kansasii: Implications for epidemiological and pathogenicity studies. J. Clin. Microbiol. 1997, 35, 1959-1964. [CrossRef]

11. Biet, F.; Boschiroli, M.L.; Thorel, M.F.; Guilloteau, L.A. Zoonotic aspects of Mycobacterium bovis and Mycobacterium aviumintracellulare complex (MAC). Vet. Res. 2005, 36, 411-436. [CrossRef]

12. Michel, A.L.; Müller, B.; Van Helden, P.D. Mycobacterium bovis at the animal-human interface: A problem, or not? Vet. Microbiol. 2010, 140, 371-381. [CrossRef] [PubMed]

13. WHO. Global Tuberculosis Report 2020; WHO: Geneva, Switzerland, 2020; pp. 39-43.

14. Manabe, Y.C.; Bishai, W.R. Latent Mycobacterium tuberculosis-persistence, patience, and winning by waiting. Nat. Med. 2000, 6, 1327-1329. [CrossRef]

15. Wayne, L.G.; Sohaskey, C.D. Nonreplicating persistence of Mycobacterium tuberculosis. Annu. Rev. Microbiol. 2001, 55, 139-163. [CrossRef]

16. Parrish, N.M.; Dick, J.D.; Bishai, W.R. Mechanisms of latency in Mycobacterium tuberculosis. Trends Microbiol. 1998, 6, 107-112. [CrossRef]

17. Rustad, T.R.; Sherrid, A.M.; Minch, K.J.; Sherman, D.R. Hypoxia: A window into Mycobacterium tuberculosis latency. Cell. Microbiol. 2009, 11, 1151-1159. [CrossRef] [PubMed]

18. Gupta, A.; Kaul, A.; Tsolaki, A.G.; Kishore, U.; Bhakta, S. Mycobacterium tuberculosis: Immune evasion, latency and reactivation. Immunobiology 2012, 217, 363-374. [CrossRef] [PubMed]

19. Getahun, H.; Matteelli, A.; Chaisson, R.E.; Raviglione, M. Latent Mycobacterium tuberculosis infection. N. Engl. J. Med. 2015, 372, 2127-2135. [CrossRef] [PubMed]

20. Fontán, P.; Aris, V.; Ghanny, S.; Soteropoulos, P.; Smith, I. Global transcriptional profile of Mycobacterium tuberculosis during THP-1 human macrophage infection. Infect. Immun. 2008, 76, 717-725. [CrossRef]

21. Barczak, A.K.; Avraham, R.; Singh, S.; Luo, S.S.; Zhang, W.R.; Bray, M.-A.; Hinman, A.E.; Thompson, M.; Nietupski, R.M.; Golas, A. Systematic, multiparametric analysis of Mycobacterium tuberculosis intracellular infection offers insight into coordinated virulence. PLoS Pathog. 2017, 13, e1006363. [CrossRef]

22. Rengarajan, J.; Bloom, B.R.; Rubin, E.J. Genome-wide requirements for Mycobacterium tuberculosis adaptation and survival in macrophages. Proc. Natl. Acad. Sci. USA 2005, 102, 8327-8332. [CrossRef]

23. Pethe, K.; Swenson, D.L.; Alonso, S.; Anderson, J.; Wang, C.; Russell, D.G. Isolation of Mycobacterium tuberculosis mutants defective in the arrest of phagosome maturation. Proc. Natl. Acad. Sci. USA 2004, 101, 13642-13647. [CrossRef] [PubMed]

24. Koul, A.; Herget, T.; Klebl, B.; Ullrich, A. Interplay between mycobacteria and host signalling pathways. Nat. Rev. Microbiol. 2004, 2, 189-202. [CrossRef] [PubMed]

25. Warner, D.F.; Mizrahi, V. The survival kit of Mycobacterium tuberculosis. Nat. Med. 2007, 13, 282-284. [CrossRef] [PubMed]

26. Harboe, M.; Oettinger, T.; Wiker, H.G.; Rosenkrands, I.; Andersen, P. Evidence for occurrence of the ESAT-6 protein in Mycobacterium tuberculosis and virulent Mycobacterium bovis and for its absence in Mycobacterium bovis BCG. Infect. Immun. 1996, 64, 16-22. [CrossRef]

27. Renshaw, P.S.; Panagiotidou, P.; Whelan, A.; Gordon, S.V.; Hewinson, R.G.; Williamson, R.A.; Carr, M.D. Conclusive Evidence That the Major T-cell Antigens of the Mycobacterium tuberculosis Complex ESAT-6 and CFP-10 Form a Tight, 1:1 Complex and Characterization of the Structural Properties of ESAT-6, CFP-10, and the ESAT-6. CFP-10 Complex Implications for Pathogenesis and Virulence. J. Biol. Chem. 2002, 277, 21598-21603.

28. Hsu, T.; Hingley-Wilson, S.M.; Chen, B.; Chen, M.; Dai, A.Z.; Morin, P.M.; Marks, C.B.; Padiyar, J.; Goulding, C.; Gingery, M. The primary mechanism of attenuation of bacillus Calmette-Guerin is a loss of secreted lytic function required for invasion of lung interstitial tissue. Proc. Natl. Acad. Sci. USA 2003, 100, 12420-12425. [CrossRef]

29. Brodin, P.; Majlessi, L.; Marsollier, L.; De Jonge, M.I.; Bottai, D.; Demangel, C.; Hinds, J.; Neyrolles, O.; Butcher, P.D.; Leclerc, C. Dissection of ESAT-6 system 1 of Mycobacterium tuberculosis and impact on immunogenicity and virulence. Infect. Immun. 2006, 74, 88-98. [CrossRef] [PubMed]

30. Mahairas, G.G.; Sabo, P.J.; Hickey, M.J.; Singh, D.C.; Stover, C.K. Molecular analysis of genetic differences between Mycobacterium bovis BCG and virulent M. bovis. J. Bacteriol. 1996, 178, 1274-1282. [CrossRef] [PubMed] 
31. Ahmad, S.; Amoudy, H.; Thole, J.; Young, D.; Mustafa, A. Identification of a novel protein antigen encoded by a Mycobacterium tuberculosis-Specific RD1 region gene. Scand. J. Immunol. 1999, 49, 515-522. [CrossRef] [PubMed]

32. Bunduc, C.M.; Bitter, W.; Houben, E. Structure and Function of the Mycobacterial Type VII Secretion Systems. Annu. Rev. Microbiol. 2020, 74, 315-335. [CrossRef] [PubMed]

33. Rivera-Calzada, A.; Famelis, N.; Llorca, O.; Geibel, S. Type VII secretion systems: Structure, functions and transport models. Nat. Rev. Microbiol. 2021, 1-18. [CrossRef]

34. Sørensen, A.L.; Nagai, S.; Houen, G.; Andersen, P.; Andersen, A.B. Purification and characterization of a low-molecular-mass T-cell antigen secreted by Mycobacterium tuberculosis. Infect. Immun. 1995, 63, 1710-1717. [CrossRef] [PubMed]

35. Ravn, P.; Demissie, A.; Eguale, T.; Wondwosson, H.; Lein, D.; Amoudy, H.A.; Mustafa, A.S.; Jensen, A.K.; Holm, A.; Rosenkrands, I. Human T cell responses to the ESAT-6 antigen from Mycobacterium tuberculosis. J. Infect. Dis. 1999, 179, 637-645. [CrossRef]

36. Mustafa, A.; Oftung, F.; Amoudy, H.; Madi, N.; Abal, A.; Shaban, F.; Rosen Krands, I.; Andersen, P. Multiple epitopes from the Mycobacterium tuberculosis ESAT-6 antigen are recognized by antigen-specific human T cell lines. Clin. Infect. Dis. 2000, 30, S201-S205. [CrossRef]

37. Brandt, L.; Elhay, M.; Rosenkrands, I.; Lindblad, E.B.; Andersen, P. ESAT-6 Subunit Vaccination against Mycobacterium tuberculosis. Infect. Immun. 2000, 68, 791-795. [CrossRef]

38. Olsen, A.W.; van Pinxteren, L.A.; Okkels, L.M.; Rasmussen, P.B.; Andersen, P. Protection of mice with a tuberculosis subunit vaccine based on a fusion protein of antigen $85 \mathrm{~b}$ and esat-6. Infect. Immun. 2001, 69, 2773-2778. [CrossRef]

39. Pym, A.S.; Brodin, P.; Majlessi, L.; Brosch, R.; Demangel, C.; Williams, A.; Griffiths, K.E.; Marchal, G.; Leclerc, C.; Cole, S.T. Recombinant BCG exporting ESAT-6 confers enhanced protection against tuberculosis. Nat. Med. 2003, 9, 533-539. [CrossRef]

40. Moguche, A.O.; Musvosvi, M.; Penn-Nicholson, A.; Plumlee, C.R.; Mearns, H.; Geldenhuys, H.; Smit, E.; Abrahams, D.; Rozot, V.; Dintwe, O. Antigen availability shapes T cell differentiation and function during tuberculosis. Cell Host Microbe 2017, 21, 695-706.e695. [CrossRef]

41. Singhal, N.; Sharma, P.; Kumar, M.; Joshi, B.; Bisht, D. Analysis of intracellular expressed proteins of Mycobacterium tuberculosis clinical isolates. Proteome Sci. 2012, 10,14. [CrossRef]

42. Gao, L.Y.; Guo, S.; McLaughlin, B.; Morisaki, H.; Engel, J.N.; Brown, E.J. A mycobacterial virulence gene cluster extending RD1 is required for cytolysis, bacterial spreading and ESAT-6 secretion. Mol. Microbiol. 2004, 53, 1677-1693. [CrossRef]

43. Lienard, J.; Nobs, E.; Lovins, V.; Movert, E.; Valfridsson, C.; Carlsson, F. The Mycobacterium marinum ESX-1 system mediates phagosomal permeabilization and type I interferon production via separable mechanisms. Proc. Natl. Acad. Sci. USA 2020, 117, 1160-1166. [CrossRef] [PubMed]

44. Zhang, Q.; Wang, D.; Jiang, G.; Liu, W.; Deng, Q.; Li, X.; Qian, W.; Ouellet, H.; Sun, J. EsxA membrane-permeabilizing activity plays a key role in mycobacterial cytosolic translocation and virulence: Effects of single-residue mutations at glutamine 5. Sci. Rep. 2016, 6, 32618. [CrossRef] [PubMed]

45. Acosta, Y.; Zhang, Q.; Rahaman, A.; Ouellet, H.; Xiao, C.; Sun, J.; Li, C. Imaging cytosolic translocation of Mycobacteria with two-photon fluorescence resonance energy transfer microscopy. Biomed. Opt. Express 2014, 5, 3990-4001. [CrossRef]

46. De Leon, J.; Jiang, G.; Ma, Y.; Rubin, E.; Fortune, S.; Sun, J. Mycobacterium tuberculosis ESAT-6 exhibits a unique membraneinteracting activity that is not found in its ortholog from non-pathogenic Mycobacterium smegmatis. J. Biol. Chem. 2012, 287, 44184-44191. [CrossRef] [PubMed]

47. Welin, A.; Lerm, M. Inside or outside the phagosome? The controversy of the intracellular localization of Mycobacterium tuberculosis. Tuberculosis 2012, 92, 113-120. [CrossRef]

48. Houben, D.; Demangel, C.; Van Ingen, J.; Perez, J.; Baldeón, L.; Abdallah, A.M.; Caleechurn, L.; Bottai, D.; Van Zon, M.; De Punder, K. ESX-1-mediated translocation to the cytosol controls virulence of mycobacteria. Cell. Microbiol. 2012, 14, 1287-1298. [CrossRef]

49. Simeone, R.; Bobard, A.; Lippmann, J.; Bitter, W.; Majlessi, L.; Brosch, R.; Enninga, J. Phagosomal rupture by Mycobacterium tuberculosis results in toxicity and host cell death. PLoS Pathog. 2012, 8, e1002507. [CrossRef]

50. Smith, J.; Manoranjan, J.; Pan, M.; Bohsali, A.; Xu, J.; Liu, J.; McDonald, K.L.; Szyk, A.; LaRonde-LeBlanc, N.; Gao, L.-Y. Evidence for pore formation in host cell membranes by ESX-1-secreted ESAT-6 and its role in Mycobacterium marinum escape from the vacuole. Infect. Immun. 2008, 76, 5478-5487. [CrossRef] [PubMed]

51. Van der Wel, N.; Hava, D.; Houben, D.; Fluitsma, D.; van Zon, M.; Pierson, J.; Brenner, M.; Peters, P.J.M. tuberculosis and M. leprae translocate from the phagolysosome to the cytosol in myeloid cells. Cell 2007, 129, 1287-1298. [CrossRef]

52. Mcdonough, K.A.; Kress, Y.; Bloom, B. Pathogenesis of tuberculosis: Interaction of Mycobacterium tuberculosis with macrophages. Infect. Immun. 1993, 61, 2763-2773. [CrossRef]

53. Conrad, W.H.; Osman, M.M.; Shanahan, J.K.; Chu, F.; Takaki, K.K.; Cameron, J.; Hopkinson-Woolley, D.; Brosch, R.; Ramakrishnan, L. Mycobacterial ESX-1 secretion system mediates host cell lysis through bacterium contact-dependent gross membrane disruptions. Proc. Natl. Acad. Sci. USA 2017, 114, 1371-1376. [CrossRef]

54. Champion, M.M.; Williams, E.A.; Pinapati, R.S.; Champion, P.A.D. Correlation of phenotypic profiles using targeted proteomics identifies mycobacterial esx-1 substrates. J. Proteome Res. 2014, 13, 5151-5164. [CrossRef]

55. Chirakos, A.E.; Nicholson, K.R.; Huffman, A.; Champion, P.A. Conserved ESX-1 substrates EspE and EspF are virulence factors that regulate gene expression. Infect. Immun. 2020, 88, e00289-20. [CrossRef] 
56. Mishra, B.B.; Moura-Alves, P.; Sonawane, A.; Hacohen, N.; Griffiths, G.; Moita, L.F.; Anes, E. Mycobacterium tuberculosis protein ESAT-6 is a potent activator of the NLRP3/ASC inflammasome. Cell. Microbiol. 2010, 12, 1046-1063. [CrossRef]

57. Pathak, S.K.; Basu, S.; Basu, K.K.; Banerjee, A.; Pathak, S.; Bhattacharyya, A.; Kaisho, T.; Kundu, M.; Basu, J. Direct extracellular interaction between the early secreted antigen ESAT- 6 of Mycobacterium tuberculosis and TLR2 inhibits TLR signaling in macrophages. Nat. Immunol. 2007, 8, 610-618. [CrossRef] [PubMed]

58. Sreejit, G.; Ahmed, A.; Parveen, N.; Jha, V.; Valluri, V.L.; Ghosh, S.; Mukhopadhyay, S. The ESAT-6 protein of Mycobacterium tuberculosis interacts with beta-2-microglobulin $(\beta 2 \mathrm{M})$ affecting antigen presentation function of macrophage. PLoS Pathog. 2014, 10, e1004446. [CrossRef]

59. Kinhikar, A.G.; Verma, I.; Chandra, D.; Singh, K.K.; Weldingh, K.; Andersen, P.; Hsu, T.; Jacobs, W.R., Jr.; Laal, S. Potential role for ESAT6 in dissemination of M. tuberculosis via human lung epithelial cells. Mol. Microbiol. 2010, 75, 92-106. [CrossRef] [PubMed]

60. Khan, H.S.; Nair, V.R.; Ruhl, C.R.; Alvarez-Arguedas, S.; Rendiz, J.L.G.; Franco, L.H.; Huang, L.; Shaul, P.W.; Kim, J.; Xie, Y. Identification of scavenger receptor B1 as the airway microfold cell receptor for Mycobacterium tuberculosis. eLife 2020, 9, e52551. [CrossRef] [PubMed]

61. Ma, Y.; Keil, V.; Sun, J. Characterization of Mycobacterium tuberculosis EsxA membrane insertion roles of N-and C-terminal flexible arms and central helix-turn-helix motif. J. Biol. Chem. 2015, 290, 7314-7322. [CrossRef] [PubMed]

62. Guinn, K.M.; Hickey, M.J.; Mathur, S.K.; Zakel, K.L.; Grotzke, J.E.; Lewinsohn, D.M.; Smith, S.; Sherman, D.R. Individual RD1-region genes are required for export of ESAT-6/CFP-10 and for virulence of Mycobacterium tuberculosis. Mol. Microbiol. 2004, 51, 359-370. [CrossRef] [PubMed]

63. Pym, A.S.; Brodin, P.; Brosch, R.; Huerre, M.; Cole, S.T. Loss of RD1 contributed to the attenuation of the live tuberculosis vaccines Mycobacterium bovis BCG and Mycobacterium microti. Mol. Microbiol. 2002, 46, 709-717. [CrossRef] [PubMed]

64. Lewis, K.N.; Liao, R.; Guinn, K.M.; Hickey, M.J.; Smith, S.; Behr, M.A.; Sherman, D.R. Deletion of RD1 from Mycobacterium tuberculosis mimics bacille Calmette-Guerin attenuation. J. Infect. Dis. 2003, 187, 117-123. [CrossRef] [PubMed]

65. Stanley, S.A.; Raghavan, S.; Hwang, W.W.; Cox, J.S. Acute infection and macrophage subversion by Mycobacterium tuberculosis require a specialized secretion system. Proc. Natl. Acad. Sci. USA 2003, 100, 13001-13006. [CrossRef]

66. Cole, S.; Brosch, R.; Parkhill, J.; Garnier, T.; Churcher, C.; Harris, D.; Gordon, S.; Eiglmeier, K.; Gas, S.; Barry, C.R. Deciphering the biology of Mycobacterium tuberculosis from the complete genome sequence. Nature 1998, 396, 190. [CrossRef]

67. De Jonge, M.I.; Pehau-Arnaudet, G.; Fretz, M.M.; Romain, F.; Bottai, D.; Brodin, P.; Honoré, N.; Marchal, G.; Jiskoot, W.; England, P.; et al. ESAT-6 from Mycobacterium tuberculosis Dissociates from Its Putative Chaperone CFP-10 under Acidic Conditions and Exhibits Membrane-Lysing Activity. J. Bacteriol. 2007, 189, 6028-6034. [CrossRef]

68. Van Pittius, N.C.G.; Gamieldien, J.; Hide, W.; Brown, G.D.; Siezen, R.J.; Beyers, A.D. The ESAT-6 gene cluster of Mycobacterium tuberculosis and other high G+ C Gram-positive bacteria. Genome Biol. 2001, 2. [CrossRef]

69. Geluk, A.; van Meijgaarden, K.E.; Franken, K.L.; Subronto, Y.W.; Wieles, B.; Arend, S.M.; Sampaio, E.P.; de Boer, T.; Faber, W.R.; Naafs, B. Identification and characterization of the ESAT-6 homologue of Mycobacterium leprae and T-cell cross-reactivity with Mycobacterium tuberculosis. Infect. Immun. 2002, 70, 2544-2548. [CrossRef]

70. Arend, S.M.; van Meijgaarden, K.E.; de Boer, K.; de Palou, E.C.; van Soolingen, D.; Ottenhoff, T.H.; van Dissel, J.T. Tuberculin skin testing and in vitro T cell responses to ESAT-6 and culture filtrate protein 10 after infection with Mycobacterium marinum or M. kansasii. J. Infect. Dis. 2002, 186, 1797-1807. [CrossRef]

71. Bao, Y.; Wang, L.; Sun, J. Post-translational knockdown and post-secretional modification of EsxA determine contribution of EsxA membrane permeabilizing activity for mycobacterial intracellular survival. Virulence 2020. [CrossRef]

72. Peng, X.; Jiang, G.; Liu, W.; Zhang, Q.; Qian, W.; Sun, J. Characterization of differential pore-forming activities of ESAT-6 proteins from Mycobacterium tuberculosis and Mycobacterium smegmatis. FEBS Lett. 2016, 590, 509-519. [CrossRef] [PubMed]

73. Converse, S.E.; Cox, J.S. A protein secretion pathway critical for Mycobacterium tuberculosis virulence is conserved and functional in Mycobacterium smegmatis. J. Bacteriol. 2005, 187, 1238-1245. [CrossRef]

74. Coros, A.; Callahan, B.; Battaglioli, E.; Derbyshire, K.M. The specialized secretory apparatus ESX-1 is essential for DNA transfer in Mycobacterium smegmatis. Mol. Microbiol. 2008, 69, 794-808.

75. Fortune, S.; Jaeger, A.; Sarracino, D.; Chase, M.; Sassetti, C.; Sherman, D.; Bloom, B.; Rubin, E. Mutually dependent secretion of proteins required for mycobacterial virulence. Proc. Natl. Acad. Sci. USA 2005, 102, 10676-10681. [CrossRef] [PubMed]

76. Champion, P.A.D.; Stanley, S.A.; Champion, M.M.; Brown, E.J.; Cox, J.S. C-terminal signal sequence promotes virulence factor secretion in Mycobacterium tuberculosis. Science 2006, 313, 1632-1636. [CrossRef]

77. Brodin, P.; de Jonge, M.I.; Majlessi, L.; Leclerc, C.; Nilges, M.; Cole, S.T.; Brosch, R. Functional analysis of early secreted antigenic target-6, the dominant T-cell antigen of Mycobacterium tuberculosis, reveals key residues involved in secretion, complex formation, virulence, and immunogenicity. J. Biol. Chem. 2005, 280, 33953-33959. [CrossRef] [PubMed]

78. Renshaw, P.S.; Lightbody, K.L.; Veverka, V.; Muskett, F.W.; Kelly, G.; Frenkiel, T.A.; Gordon, S.V.; Hewinson, R.G.; Burke, B.; Norman, J. Structure and function of the complex formed by the tuberculosis virulence factors CFP-10 and ESAT-6. EMBO J. 2005, 24, 2491-2498. [CrossRef]

79. Lightbody, K.L.; Ilghari, D.; Waters, L.C.; Carey, G.; Bailey, M.A.; Williamson, R.A.; Renshaw, P.S.; Carr, M.D. Molecular features governing the stability and specificity of functional complex formation by Mycobacterium tuberculosis CFP-10/ESAT-6 family proteins. J. Biol. Chem. 2008, 283, 17681-17690. [CrossRef] 
80. Zhang, L.; Zhang, H.; Zhao, Y.; Mao, F.; Wu, J.; Bai, B.; Xu, Z.; Jiang, Y.; Shi, C. Effects of Mycobacterium tuberculosis ESAT-6/CFP-10 fusion protein on the autophagy function of mouse macrophages. DNA Cell Biol. 2012, 31, 171-179. [CrossRef]

81. Ganguly, N.; Giang, P.H.; Gupta, C.; Basu, S.K.; Siddiqui, I.; Salunke, D.M.; Sharma, P. Mycobacterium tuberculosis secretory proteins CFP-10, ESAT-6 and the CFP10: ESAT6 complex inhibit lipopolysaccharide-induced NF- $\mathrm{kB}$ transactivation by downregulation of reactive oxidative species (ROS) production. Immunol. Cell Biol. 2008, 86, 98-106. [CrossRef]

82. Peng, X.; Sun, J. Mechanism of ESAT-6 membrane interaction and its roles in pathogenesis of Mycobacterium tuberculosis. Toxicon 2016, 116, 29-34. [CrossRef] [PubMed]

83. Okkels, L.M.; Müller, E.C.; Schmid, M.; Rosenkrands, I.; Kaufmann, S.H.; Andersen, P.; Jungblut, P.R. CFP10 discriminates between nonacetylated and acetylated ESAT-6 of Mycobacterium tuberculosis by differential interaction. Proteomics 2004, 4, 2954-2960. [CrossRef]

84. Poulsen, C.; Holton, S.; Geerlof, A.; Wilmanns, M.; Song, Y.-H. Stoichiometric protein complex formation and over-expression using the prokaryotic native operon structure. FEBS Lett. 2010, 584, 669-674. [CrossRef] [PubMed]

85. Medie, F.M.; Champion, M.M.; Williams, E.A.; Champion, P.A.D. Homeostasis of N- $\alpha$-terminal acetylation of EsxA correlates with virulence in Mycobacterium marinum. Infect. Immun. 2014, 82, 4572-4586. [CrossRef] [PubMed]

86. Aguilera, J.; Karki, C.B.; Li, L.; Reyes, S.V.; Estevao, I.; Grajeda, B.I.; Zhang, Q.; Arico, C.D.; Ouellet, H.; Sun, J. N $\alpha$-Acetylation of the virulence factor EsxA is required for mycobacterial cytosolic translocation and virulence. J. Biol. Chem. 2020, 295, 5785-5794. [CrossRef] [PubMed]

87. Chatterjee, S.; Dwivedi, V.P.; Singh, Y.; Siddiqui, I.; Sharma, P.; Van Kaer, L.; Chattopadhyay, D.; Das, G. Early secreted antigen ESAT-6 of Mycobacterium tuberculosis promotes protective T helper 17 cell responses in a toll-like receptor-2-dependent manner. PLoS Pathog. 2011, 7, e1002378. [CrossRef]

88. Brandt, L.; Oettinger, T.; Holm, A.; Andersen, A.B.; Andersen, P. Key epitopes on the ESAT-6 antigen recognized in mice during the recall of protective immunity to Mycobacterium tuberculosis. J. Immunol. 1996, 157, 3527-3533.

89. Ulrichs, T.; Munk, M.E.; Mollenkopf, H.; Behr-Perst, S.; Colangeli, R.; Gennaro, M.L.; Kaufmann, S.H. Differential T cell responses to Mycobacterium tuberculosis ESAT6 in tuberculosis patients and healthy donors. Eur. J. Immunol. 1998, 28, 3949-3958. [CrossRef]

90. Kellar, K.L.; Gehrke, J.; Weis, S.E.; Mahmutovic-Mayhew, A.; Davila, B.; Zajdowicz, M.J.; Scarborough, R.; LoBue, P.A.; Lardizabal, A.A.; Daley, C.L. Multiple cytokines are released when blood from patients with tuberculosis is stimulated with Mycobacterium tuberculosis antigens. PLoS ONE 2011, 6, e26545. [CrossRef]

91. Marei, A.; Ghaemmaghami, A.; Renshaw, P.; Wiselka, M.; Barer, M.; Carr, M.; Ziegler-Heitbrock, L. Superior T cell activation by ESAT-6 as compared with the ESAT-6-CFP-10 complex. Int. Immunol. 2005, 17, 1439-1446. [CrossRef] [PubMed]

92. Mattos, A.M.M.; Almeida, C.D.S.; Franken, K.L.; Alves, C.C.D.S.; Abramo, C.; de Souza, M.A.; L'Hotellier, M.; Alves, M.J.; Ferreira, A.P.; Oliveira, S.C. Increased IgG1, IFN- $\gamma$, TNF- $\alpha$ and IL-6 responses to Mycobacterium tuberculosis antigens in patients with tuberculosis are lower after chemotherapy. Int. Immunol. 2010, 22, 775-782. [CrossRef]

93. Kaufmann, S.H. Immunity to intracellular bacteria. Annu. Rev. Immunol. 1993, 11, 129-163. [CrossRef] [PubMed]

94. Flynn, J.L.; Chan, J.; Triebold, K.J.; Dalton, D.K.; Stewart, T.A.; Bloom, B.R. An essential role for interferon gamma in resistance to Mycobacterium tuberculosis infection. J. Exp. Med. 1993, 178, 2249-2254. [CrossRef] [PubMed]

95. MacMicking, J.D.; Taylor, G.A.; McKinney, J.D. Immune control of tuberculosis by IFN- $\gamma$-inducible LRG-47. Science 2003, 302, 654-659. [CrossRef]

96. Sada-Ovalle, I.; Chiba, A.; Gonzales, A.; Brenner, M.B.; Behar, S.M. Innate invariant NKT cells recognize Mycobacterium tuberculosisinfected macrophages, produce interferon- $\gamma$, and kill intracellular bacteria. PLoS Pathog. 2008, 4, e1000239. [CrossRef]

97. Cooper, A.M.; Dalton, D.K.; Stewart, T.A.; Griffin, J.P.; Russell, D.G.; Orme, I.M. Disseminated tuberculosis in interferon gamma gene-disrupted mice. J. Exp. Med. 1993, 178, 2243-2247. [CrossRef]

98. Newport, M.J.; Huxley, C.M.; Huston, S.; Hawrylowicz, C.M.; Oostra, B.A.; Williamson, R.; Levin, M. A mutation in the interferon- $\gamma$-receptor gene and susceptibility to mycobacterial infection. N. Engl. J. Med. 1996, 335, 1941-1949. [CrossRef] [PubMed]

99. Ottenhoff, T.H.; Verreck, F.A.; Hoeve, M.A.; van de Vosse, E. Control of human host immunity to mycobacteria. Tuberculosis 2005, 85, 53-64. [CrossRef]

100. Keane, J.; Balcewicz-Sablinska, M.K.; Remold, H.G.; Chupp, G.L.; Meek, B.B.; Fenton, M.J.; Kornfeld, H. Infection by Mycobacterium tuberculosis promotes human alveolar macrophage apoptosis. Infect. Immun. 1997, 65, 298-304. [CrossRef]

101. Flynn, J.L.; Goldstein, M.M.; Chan, J.; Triebold, K.J.; Pfeffer, K.; Lowenstein, C.J.; Schrelber, R.; Mak, T.W.; Bloom, B.R. Tumor necrosis factor- $\alpha$ is required in the protective immune response against Mycobacterium tuberculosis in mice. Immunity 1995, 2, 561-572. [CrossRef]

102. Scanga, C.A.; Mohan, V.; Yu, K.; Joseph, H.; Tanaka, K.; Chan, J.; Flynn, J.L. Depletion of CD4+ T cells causes reactivation of murine persistent tuberculosis despite continued expression of interferon $\gamma$ and nitric oxide synthase 2. J. Exp. Med. 2000, 192, 347-358. [CrossRef] [PubMed]

103. Flynn, J.L.; Scanga, C.A.; Tanaka, K.E.; Chan, J. Effects of aminoguanidine on latent murine tuberculosis. J. Immunol. 1998, 160, 1796-1803. [PubMed]

104. Mohan, V.P.; Scanga, C.A.; Yu, K.; Scott, H.M.; Tanaka, K.E.; Tsang, E.; Tsai, M.C.; Flynn, J.L.; Chan, J. Effects of tumor necrosis factor alpha on host immune response in chronic persistent tuberculosis: Possible role for limiting pathology. Infect. Immun. 2001, 69, 1847-1855. [CrossRef] [PubMed] 
105. Taniguchi, T.; Minami, Y. The IL-2IL-2 receptor system: A current overview. Cell 1993, 73, 5-8. [CrossRef]

106. Hussain, R.; Kaleem, A.; Shahid, F.; Dojki, M.; Jamil, B.; Mehmood, H.; Dawood, G.; Dockrell, H.M. Cytokine profiles using whole-blood assays can discriminate between tuberculosis patients and healthy endemic controls in a BCG-vaccinated population. J. Immunol. Methods 2002, 264, 95-108. [CrossRef]

107. Sargentini, V.; Mariotti, S.; Carrara, S.; Gagliardi, M.C.; Teloni, R.; Goletti, D.; Nisini, R. Cytometric detection of antigen-specific IFN- $\gamma /$ IL-2 secreting cells in the diagnosis of tuberculosis. BMC Infect. Dis. 2009, 9, 1-10. [CrossRef]

108. Biselli, R.; Mariotti, S.; Sargentini, V.; Sauzullo, I.; Lastilla, M.; Mengoni, F.; Vanini, V.; Girardi, E.; Goletti, D.; D’Amelio, R. Detection of interleukin-2 in addition to interferon- $\gamma$ discriminates active tuberculosis patients, latently infected individuals, and controls. Clin. Microbiol. Infect. 2010, 16, 1282-1284. [CrossRef] [PubMed]

109. Sester, U.; Fousse, M.; Dirks, J.; Mack, U.; Prasse, A.; Singh, M.; Lalvani, A.; Sester, M. Whole-blood flow-cytometric analysis of antigen-specific CD4 T-cell cytokine profiles distinguishes active tuberculosis from non-active states. PLoS ONE 2011, 6, e17813. [CrossRef]

110. Ladel, C.H.; Blum, C.; Dreher, A.; Reifenberg, K.; Kopf, M.; Kaufmann, S. Lethal tuberculosis in interleukin-6-deficient mutant mice. Infect. Immun. 1997, 65, 4843-4849. [CrossRef]

111. Saunders, B.M.; Frank, A.A.; Orme, I.M.; Cooper, A.M. Interleukin-6 Induces Early Gamma Interferon Production in the Infected Lung but Is Not Required for Generation of Specific Immunity to Mycobacterium tuberculosis Infection. Infect. Immun. 2000, 68, 3322-3326. [CrossRef] [PubMed]

112. Leal, I.S.; Smedegård, B.; Andersen, P.; Appelberg, R. Interleukin-6 and interleukin-12 participate in induction of a type 1 protective T-cell response during vaccination with a tuberculosis subunit vaccine. Infect. Immun. 1999, 67, 5747-5754. [CrossRef]

113. Martinez, A.N.; Mehra, S.; Kaushal, D. Role of interleukin 6 in innate immunity to Mycobacterium tuberculosis infection. J. Infect. Dis. 2013, 207, 1253-1261. [CrossRef] [PubMed]

114. Nagabhushanam, V.; Solache, A.; Ting, L.-M.; Escaron, C.J.; Zhang, J.Y.; Ernst, J.D. Innate inhibition of adaptive immunity: Mycobacterium tuberculosis-induced IL-6 inhibits macrophage responses to IFN- $\gamma$. J. Immunol. 2003, 171, 4750-4757. [CrossRef]

115. Sodenkamp, J.; Waetzig, G.H.; Scheller, J.; Seegert, D.; Grötzinger, J.; Rose-John, S.; Ehlers, S.; Hölscher, C. Therapeutic targeting of interleukin-6 trans-signaling does not affect the outcome of experimental tuberculosis. Immunobiology 2012, 217, 996-1004. [CrossRef] [PubMed]

116. Fiorentino, D.F.; Bond, M.W.; Mosmann, T. Two types of mouse T helper cell. IV. Th2 clones secrete a factor that inhibits cytokine production by Th1 clones. J. Exp. Med. 1989, 170, 2081-2095. [CrossRef] [PubMed]

117. Fulton, S.; Cross, J.; Toossi, Z.; Boom, W. Regulation of interleukin-12 by interleukin-10, transforming growth factor- $\beta$, tumor necrosis factor- $\alpha$, and interferon- $\gamma$ in human monocytes infected with Mycobacterium tuberculosis H37Ra. J. Infect. Dis. 1998, 178, 1105-1114. [CrossRef] [PubMed]

118. Redford, P.S.; Boonstra, A.; Read, S.; Pitt, J.; Graham, C.; Stavropoulos, E.; Bancroft, G.J.; O'Garra, A. Enhanced protection to Mycobacterium tuberculosis infection in IL-10-deficient mice is accompanied by early and enhanced Th1 responses in the lung. Eur. J. Immunol. 2010, 40, 2200-2210. [CrossRef]

119. O'Leary, S.N.; O'Sullivan, M.P.; Keane, J. IL-10 blocks phagosome maturation in Mycobacterium tuberculosis-infected human macrophages. Am. J. Respir. Cell Mol. Biol. 2011, 45, 172-180. [CrossRef]

120. Rojas, M.; Olivier, M.; Gros, P.; Barrera, L.F.; García, L.F. TNF- $\alpha$ and IL-10 modulate the induction of apoptosis by virulent Mycobacterium tuberculosis in murine macrophages. J. Immunol. 1999, 162, 6122-6131.

121. Flynn, J.L.; Chan, J. Immunology of tuberculosis. Annu. Rev. Immunol. 2001, 19, 93-129. [CrossRef]

122. Slight, S.R.; Khader, S.A. Chemokines shape the immune responses to tuberculosis. Cytokine Growth Factor Rev. 2013, $24,105-113$. [CrossRef]

123. Monin, L.; Khader, S.A. Chemokines in tuberculosis: The good, the bad and the ugly. Semin. Immunol. 2014, 26, 552-558. [CrossRef] [PubMed]

124. Friedland, J.S.; Remick, D.G.; Shattock, R.; Griffin, G.E. Secretion of interleukin-8 following phagocytosis of Mycobacterium tuberculosis by human monocyte cell lines. Eur. J. Immunol. 1992, 22, 1373-1378. [CrossRef] [PubMed]

125. Zhang, Y.; Broser, M.; Cohen, H.; Bodkin, M.; Law, K.; Reibman, J.; Rom, W.N. Enhanced interleukin-8 release and gene expression in macrophages after exposure to Mycobacterium tuberculosis and its components. J. Clin. Investig. 1995, 95, 586-592. [CrossRef]

126. Smyth, M.J.; Zachariae, C.; Norihisa, Y.; Ortaldo, J.R.; Hishinuma, A.; Matsushima, K. IL-8 gene expression and production in human peripheral blood lymphocyte subsets. J. Immunol. 1991, 146, 3815-3823. [PubMed]

127. Lin, Y.; Zhang, M.; Barnes, P.F. Chemokine production by a human alveolar epithelial cell line in response to Mycobacterium tuberculosis. Infect. Immun. 1998, 66, 1121-1126. [CrossRef]

128. Kasahara, K.; Sato, I.; Ogura, K.; Takeuchi, H.; Kobayashi, K.; Adachi, M. Expression of chemokines and induction of rapid cell death in human blood neutrophils by Mycobacterium tuberculosis. J. Infect. Dis. 1998, 178, 127-137. [CrossRef] [PubMed]

129. Sadek, M.I.; Sada, E.; Toossi, Z.; Schwander, S.K.; Rich, E.A. Chemokines induced by infection of mononuclear phagocytes with mycobacteria and present in lung alveoli during active pulmonary tuberculosis. Am. J. Respir. Cell Mol. Biol. 1998, 19, 513-521. [CrossRef]

130. Dlugovitzky, D.; Rateni, L.; Torres-Morales, A.; Ruiz-Silva, J.; Piñesky, R.; Canosa, B.; Molteni, O.; Bottasso, O. Levels of interleukin8 in tuberculous pleurisy and the profile of immunocompetent cells in pleural and peripheral compartments. Immunol. Lett. 1997, 55, 35-39. [CrossRef] 
131. Mastroianni, C.M.; Paoletti, F.; Rivosecchi, R.M.; Lancella, L.; Ticca, F. Cerebrospinal fluit interleukin 8 in children with purulent bacterial and tuberculous meningitis. Pediatric Infect. Dis. J. 1994, 13, 1008-1010.

132. Larsen, C.G.; Thomsen, M.K.; Gesser, B.; Thomsen, P.D.; Deleuran, B.W.; Nowak, J.; Skødt, V.; Thomsen, H.K.; Deleuran, M.; Thestrup-Pedersen, K. The delayed-type hypersensitivity reaction is dependent on IL-8. Inhibition of a tuberculin skin reaction by an anti-IL-8 monoclonal antibody. J. Immunol. 1995, 155, 2151-2157. [PubMed]

133. Fietta, A.M.; Morosini, M.; Meloni, F.; Bianco, A.M.; Pozzi, E. Pharmacological analysis of signal transduction pathways required for Mycobacterium tuberculosis-induced IL-8 and MCP-1 production in human peripheral monocytes. Cytokine 2002, 19, 242-249. [CrossRef]

134. Brieland, J.K.; Flory, C.M.; Jones, M.L.; Miller, G.R.; Remick, D.G.; Warren, J.S.; Fantone, J.C. Regulation of monocyte chemoattractant protein-1 gene expression and secretion in rat pulmonary alveolar macrophages by lipopolysaccharide, tumor necrosis factor-alpha, and interleukin-1 beta. Am. J. Respir. Cell Mol. Biol. 1995, 12, 104-109. [CrossRef]

135. Schwander, S.; Sada, E.; Torres, M.; Escobedo, D.; Sierra, J.; Alt, S.; Rich, E. T lymphocytic and immature macrophage alveolitis in active pulmonary tuberculosis. J. Infect. Dis. 1996, 173, 1267-1272. [CrossRef] [PubMed]

136. Deshmane, S.L.; Kremlev, S.; Amini, S.; Sawaya, B.E. Monocyte chemoattractant protein-1 (MCP-1): An overview. J. Interferon Cytokine Res. 2009, 29, 313-326. [CrossRef]

137. Hilda, J.N.; Narasimhan, M.; Das, S.D. Neutrophils from pulmonary tuberculosis patients show augmented levels of chemokines MIP-1 $\alpha$, IL-8 and MCP-1 which further increase upon in vitro infection with mycobacterial strains. Hum. Immunol. 2014, 75, 914-922. [CrossRef]

138. Saukkonen, J.J.; Bazydlo, B.; Thomas, M.; Strieter, R.M.; Keane, J.; Kornfeld, H. $\beta$-Chemokines are induced by Mycobacterium tuberculosis and inhibit its growth. Infect. Immun. 2002, 70, 1684-1693. [CrossRef] [PubMed]

139. Reichel, C.A.; Rehberg, M.; Lerchenberger, M.; Berberich, N.; Bihari, P.; Khandoga, A.G.; Zahler, S.; Krombach, F. Ccl2 and $\mathrm{Ccl} 3$ mediate neutrophil recruitment via induction of protein synthesis and generation of lipid mediators. Arterioscler. Thromb. Vasc. Biol. 2009, 29, 1787-1793. [CrossRef]

140. Karpus, W.J.; Lukacs, N.W.; Kennedy, K.J.; Smith, W.S.; Hurst, S.D.; Barrett, T.A. Differential CC chemokine-induced enhancement of T helper cell cytokine production. J. Immunol. 1997, 158, 4129-4136.

141. Karpus, W.J.; Kennedy, K.J. MIP-1 $\alpha$ and MCP-1 differentially regulate acute and relapsing autoimmune encephalomyelitis as well as Th1/Th2 lymphoctye differentiation. J. Leukoc. Biol. 1997, 62, 681-687. [CrossRef] [PubMed]

142. Kumar, M.; Sahu, S.K.; Kumar, R.; Subuddhi, A.; Maji, R.K.; Jana, K.; Gupta, P.; Raffetseder, J.; Lerm, M.; Ghosh, Z. MicroRNA let-7 modulates the immune response to Mycobacterium tuberculosis infection via control of A20, an inhibitor of the NF- $\mathrm{kB}$ pathway. Cell Host Microbe 2015, 17, 345-356. [CrossRef]

143. Kumar, R.; Halder, P.; Sahu, S.K.; Kumar, M.; Kumari, M.; Jana, K.; Ghosh, Z.; Sharma, P.; Kundu, M.; Basu, J. Identification of a novel role of ESAT-6-dependent miR-155 induction during infection of macrophages with Mycobacterium tuberculosis. Cell. Microbiol. 2012, 14, 1620-1631. [CrossRef]

144. Yang, S.; Li, F.; Jia, S.; Zhang, K.; Jiang, W.; Shang, Y.; Chang, K.; Deng, S.; Chen, M. Early secreted antigen ESAT-6 of Mycobacterium tuberculosis promotes apoptosis of macrophages via targeting the microRNA155-SOCS1 interaction. Cell. Physiol. Biochem. 2015, 35, 1276-1288. [CrossRef]

145. Etna, M.P.; Sinigaglia, A.; Grassi, A.; Giacomini, E.; Romagnoli, A.; Pardini, M.; Severa, M.; Cruciani, M.; Rizzo, F.; Anastasiadou, E. Mycobacterium tuberculosis-induced miR-155 subverts autophagy by targeting ATG3 in human dendritic cells. PLoS Pathog. 2018, 14, e1006790. [CrossRef]

146. Wu, H.; Bao, Y.; Wang, L.; Li, X.; Sun, J. Mycobacterium marinum down-regulates miR-148a in macrophages in an EsxA-dependent manner. Int. Immunopharmacol. 2019, 73, 41-48. [CrossRef] [PubMed]

147. Zuo, X.; Wang, L.; Bao, Y.; Sun, J. The ESX-1 virulence factors downregulate miR-147-3p in Mycobacterium marinum-infected macrophages. Infect. Immun. 2020, 88, e00088-20. [CrossRef] [PubMed]

148. Danelishvili, L.; McGarvey, J.; Li, Y.J.; Bermudez, L.E. Mycobacterium tuberculosis infection causes different levels of apoptosis and necrosis in human macrophages and alveolar epithelial cells. Cell. Microbiol. 2003, 5, 649-660. [CrossRef]

149. Weinrauch, Y.; Zychlinsky, A. The induction of apoptosis by bacterial pathogens. Annu. Rev. Microbiol. 1999, 53, 155-187. [CrossRef] [PubMed]

150. Welin, A.; Eklund, D.; Stendahl, O.; Lerm, M. Human macrophages infected with a high burden of ESAT-6-expressing M. tuberculosis undergo caspase-1-and cathepsin B-independent necrosis. PLoS ONE 2011, 6, e20302. [CrossRef]

151. Dobos, K.M.; Spotts, E.A.; Quinn, F.D.; King, C.H. Necrosis of Lung Epithelial Cells during Infection with Mycobacterium tuberculosis Is Preceded by Cell Permeation. Infect. Immun. 2000, 68, 6300-6310. [CrossRef]

152. Castro-Garza, J.; Swords, W.E.; Karls, R.K.; Quinn, F.D. Dual mechanism for Mycobacterium tuberculosis cytotoxicity on lung epithelial cells. Can. J. Microbiol. 2012, 58, 909-916. [CrossRef]

153. Francis, R.; Butler, R.; Stewart, G. Mycobacterium tuberculosis ESAT-6 is a leukocidin causing Ca ${ }^{2+}$ influx, necrosis and neutrophil extracellular trap formation. Cell Death Dis. 2014, 5, e1474. [CrossRef] [PubMed]

154. Dallenga, T.; Repnik, U.; Corleis, B.; Eich, J.; Reimer, R.; Griffiths, G.W.; Schaible, U.E.M. tuberculosis-induced necrosis of infected neutrophils promotes bacterial growth following phagocytosis by macrophages. Cell Host Microbe 2017, 22, 519-530.e513. [CrossRef] 
155. McDonough, K.A.; Kress, Y. Cytotoxicity for lung epithelial cells is a virulence-associated phenotype of Mycobacterium tuberculosis. Infect. Immun. 1995, 63, 4802-4811. [CrossRef]

156. Koo, I.C.; Wang, C.; Raghavan, S.; Morisaki, J.H.; Cox, J.S.; Brown, E.J. ESX-1-dependent cytolysis in lysosome secretion and inflammasome activation during mycobacterial infection. Cell. Microbiol. 2008, 10, 1866-1878. [CrossRef] [PubMed]

157. Carlsson, F.; Kim, J.; Dumitru, C.; Barck, K.H.; Carano, R.A.; Sun, M.; Diehl, L.; Brown, E.J. Host-detrimental role of Esx-1-mediated inflammasome activation in mycobacterial infection. PLoS Pathog. 2010, 6, e1000895. [CrossRef] [PubMed]

158. Wong, K.W.; Jacobs, W.R., Jr. Critical role for NLRP3 in necrotic death triggered by Mycobacterium tuberculosis. Cell. Microbiol. 2011, 13, 1371-1384. [CrossRef]

159. Amaral, E.P.; Riteau, N.; Moayeri, M.; Maier, N.; Mayer-Barber, K.D.; Pereira, R.M.; Lage, S.L.; Kubler, A.; Bishai, W.R.; D'Império-Lima, M.R. Lysosomal cathepsin release is required for NLRP3-inflammasome activation by Mycobacterium tuberculosis in infected macrophages. Front. Immunol. 2018, 9, 1427. [CrossRef]

160. Scordo, J.M.; Knoell, D.L.; Torrelles, J.B. Alveolar epithelial cells in Mycobacterium tuberculosis infection: Active players or innocent bystanders? J. Innate Immun. 2016, 8, 3-14. [CrossRef]

161. Boggaram, V.; Gottipati, K.R.; Wang, X.; Samten, B. Early secreted antigenic target of 6 kDa (ESAT-6) protein of Mycobacterium tuberculosis induces interleukin-8 (IL-8) expression in lung epithelial cells via protein kinase signaling and reactive oxygen species. J. Biol. Chem. 2013, 288, 25500-25511. [CrossRef]

162. Derrick, S.C.; Morris, S.L. The ESAT6 protein of Mycobacterium tuberculosis induces apoptosis of macrophages by activating caspase expression. Cell. Microbiol. 2007, 9, 1547-1555. [CrossRef] [PubMed]

163. Lin, J.; Chang, Q.; Dai, X.; Liu, D.; Jiang, Y.; Dai, Y. Early secreted antigenic target of 6-kDa of Mycobacterium tuberculosis promotes caspase-9/caspase-3-mediated apoptosis in macrophages. Mol. Cell. Biochem. 2019, 457, 179-189. [CrossRef]

164. Grover, A.; Izzo, A.A. BAT3 regulates Mycobacterium tuberculosis protein ESAT-6-mediated apoptosis of macrophages. PLoS ONE 2012, 7, e40836. [CrossRef]

165. Choi, H.-H.; Shin, D.-M.; Kang, G.; Kim, K.-H.; Park, J.B.; Hur, G.M.; Lee, H.-M.; Lim, Y.-J.; Park, J.-K.; Jo, E.-K. Endoplasmic reticulum stress response is involved in Mycobacterium tuberculosis protein ESAT-6-mediated apoptosis. FEBS Lett. 2010, 584, 2445-2454. [CrossRef] [PubMed]

166. Aguiló, N.; Uranga, S.; Marinova, D.; Martín, C.; Pardo, J. Bim is a crucial regulator of apoptosis induced by Mycobacterium tuberculosis. Cell Death Dis. 2014, 5, e1343. [CrossRef] [PubMed]

167. Davis, J.M.; Ramakrishnan, L. The role of the granuloma in expansion and dissemination of early tuberculous infection. Cell 2009, 136, 37-49. [CrossRef] [PubMed]

168. Todde, V.; Veenhuis, M.; van der Klei, I.J. Autophagy: Principles and significance in health and disease. Biochim. Biophys. Acta BBA Mol. Basis Dis. 2009, 1792, 3-13. [CrossRef] [PubMed]

169. Siqueira, M.D.S.; Ribeiro, R.D.M.; Travassos, L.H. Autophagy and its interaction with intracellular bacterial pathogens. Front. Immunol. 2018, 9, 935. [CrossRef]

170. Watson, R.O.; Manzanillo, P.S.; Cox, J.S. Extracellular M. tuberculosis DNA targets bacteria for autophagy by activating the host DNA-sensing pathway. Cell 2012, 150, 803-815. [CrossRef]

171. López-Jiménez, A.T.; Cardenal-Muñoz, E.; Leuba, F.; Gerstenmaier, L.; Barisch, C.; Hagedorn, M.; King, J.S.; Soldati, T. The ESCRT and autophagy machineries cooperate to repair ESX-1-dependent damage at the Mycobacterium-containing vacuole but have opposite impact on containing the infection. PLoS Pathog. 2018, 14, e1007501. [CrossRef]

172. Kimmey, J.M.; Stallings, C.L. Bacterial pathogens versus autophagy: Implications for therapeutic interventions. Trends Mol. Med. 2016, 22, 1060-1076. [CrossRef] [PubMed]

173. Gutierrez, M.G.; Master, S.S.; Singh, S.B.; Taylor, G.A.; Colombo, M.I.; Deretic, V. Autophagy is a defense mechanism inhibiting BCG and Mycobacterium tuberculosis survival in infected macrophages. Cell 2004, 119, 753-766. [CrossRef] [PubMed]

174. Romagnoli, A.; Etna, M.P.; Giacomini, E.; Pardini, M.; Remoli, M.E.; Corazzari, M.; Falasca, L.; Goletti, D.; Gafa, V.; Simeone, R. ESX-1 dependent impairment of autophagic flux by Mycobacterium tuberculosis in human dendritic cells. Autophagy 2012, 8 , 1357-1370. [CrossRef]

175. Moraco, A.H.; Kornfeld, H. Cell death and autophagy in tuberculosis. Semin. Immunol. 2014, 26, 497-511. [CrossRef] [PubMed]

176. Dong, H.; Jing, W.; Runpeng, Z.; Xuewei, X.; Min, M.; Ru, C.; Yingru, X.; Shengfa, N.; Rongbo, Z. ESAT6 inhibits autophagy flux and promotes BCG proliferation through MTOR. Biochem. Biophys. Res. Commun. 2016, 477, 195-201. [CrossRef] [PubMed]

177. Yabaji, S.M.; Dhamija, E.; Mishra, A.K.; Srivastava, K.K. ESAT-6 regulates autophagous response through SOD-2 and as a result induces intracellular survival of Mycobacterium bovis BCG. Biochim. Biophys. Acta BBA Proteins Proteom. 2020, 1868, 140470. [CrossRef]

178. Behura, A.; Mishra, A.; Chugh, S.; Mawatwal, S.; Kumar, A.; Manna, D.; Mishra, A.; Singh, R.; Dhiman, R. ESAT-6 modulates Calcimycin-induced autophagy through microRNA-30a in mycobacteria infected macrophages. J. Infect. 2019, 79, 139-152. [CrossRef]

179. Weinreich Olsen, A.; Hansen, P.R.; Holm, A.; Andersen, P. Efficient protection against Mycobacterium tuberculosis by vaccination with a single subdominant epitope from the ESAT-6 antigen. Eur. J. Immunol. 2000, 30, 1724-1732. [CrossRef]

180. Horwitz, M.A.; Lee, B.; Dillon, B.J.; Harth, G. Protective immunity against tuberculosis induced by vaccination with major extracellular proteins of Mycobacterium tuberculosis. Proc. Natl. Acad. Sci. USA 1995, 92, 1530-1534. [CrossRef] 
181. Wolf, A.J.; Desvignes, L.; Linas, B.; Banaiee, N.; Tamura, T.; Takatsu, K.; Ernst, J.D. Initiation of the adaptive immune response to Mycobacterium tuberculosis depends on antigen production in the local lymph node, not the lungs. J. Exp. Med. 2008, 205, 105-115. [CrossRef]

182. Cooper, A.M. T cells in mycobacterial infection and disease. Curr. Opin. Immunol. 2009, 21, 378-384. [CrossRef]

183. Bold, T.D.; Banaei, N.; Wolf, A.J.; Ernst, J.D. Suboptimal activation of antigen-specific CD4+ effector cells enables persistence of $M$. tuberculosis in vivo. PLoS Pathog. 2011, 7, e1002063. [CrossRef]

184. Shi, L.; North, R.; Gennaro, M.L. Effect of growth state on transcription levels of genes encoding major secreted antigens of Mycobacterium tuberculosis in the mouse lung. Infect. Immun. 2004, 72, 2420-2424. [CrossRef] [PubMed]

185. Rogerson, B.J.; Jung, Y.J.; LaCourse, R.; Ryan, L.; Enright, N.; North, R.J. Expression levels of Mycobacterium tuberculosis antigenencoding genes versus production levels of antigen-specific T cells during stationary level lung infection in mice. Immunology 2006, 118, 195-201. [CrossRef]

186. Moguche, A.O.; Shafiani, S.; Clemons, C.; Larson, R.P.; Dinh, C.; Higdon, L.E.; Cambier, C.; Sissons, J.R.; Gallegos, A.M.; Fink, P.J. ICOS and Bcl6-dependent pathways maintain a CD4 T cell population with memory-like properties during tuberculosis J. Exp. Med. 2015, 212, 715-728. [CrossRef] [PubMed]

187. Refai, A.; Haoues, M.; Othman, H.; Barbouche, M.R.; Moua, P.; Bondon, A.; Mouret, L.; Srairi-Abid, N.; Essafi, M. Two distinct conformational states of Mycobacterium tuberculosis virulent factor early secreted antigenic target $6 \mathrm{kD}$ a are behind the discrepancy around its biological functions. FEBS J. 2015, 282, 4114-4129. [CrossRef]

188. Bao, Y.; Zhang, Q.; Wang, L.; Aguilera, J.; Reyes, S.V.; Sun, J. Mycobacterial surface-associated ESX-1 virulence factors play a role in mycobacterial adherence and invasion into lung epithelial cells. bioRxiv 2020. [CrossRef]

189. Lakshmi, P.S.; Verma, D.; Yang, X.; Lloyd, B.; Daniell, H. Low cost tuberculosis vaccine antigens in capsules: Expression in chloroplasts, bio-encapsulation, stability and functional evaluation in vitro. PLoS ONE 2013, 8, e54708. [CrossRef] [PubMed]

190. Steck, T.L. The organization of proteins in the human red blood cell membrane: A review. J. Cell Biol. 1974, 62, 1-19. [CrossRef]

191. Yawata, Y. Cell Membrane: The Red Blood Cell as a Model; John Wiley \& Sons: Hoboken, NJ, USA, 2006.

192. Ray, S.; Reyes, S.V.; Xiao, C.; Sun, J. Effects of membrane lipid composition on Mycobacterium tuberculosis EsxA membrane insertion: A dual play of fluidity and charge. Tuberculosis 2019, 118, 101854. [CrossRef] [PubMed]

193. Nelson, G.J. Studies on the lipids of sheep red blood cells. I. Lipid composition in low and high potassium red cells. Lipids 1967, 2 64-71. [CrossRef] [PubMed]

194. Dawaliby, R.; Trubbia, C.; Delporte, C.; Noyon, C.; Ruysschaert, J.-M.; Van Antwerpen, P.; Govaerts, C. Phosphatidylethanolamine is a key regulator of membrane fluidity in eukaryotic cells. J. Biol. Chem. 2016, 291, 3658-3667. [CrossRef] [PubMed]

195. Dermine, J.-F.; Duclos, S.; Garin, J.; St-Louis, F.; Rea, S.; Parton, R.G.; Desjardins, M. Flotillin-1-enriched lipid raft domains accumulate on maturing phagosomes. J. Biol. Chem. 2001, 276, 18507-18512. [CrossRef]

196. Weber, S.S.; Ragaz, C.; Reus, K.; Nyfeler, Y.; Hilbi, H. Legionella pneumophila exploits PI (4) P to anchor secreted effector proteins to the replicative vacuole. PLoS Pathog 2006, 2, e46. [CrossRef]

197. Harding, C.R.; Mattheis, C.; Mousnier, A.; Oates, C.V.; Hartland, E.L.; Frankel, G.; Schroeder, G.N. LtpD is a novel Legionella pneumophila effector that binds phosphatidylinositol 3-phosphate and inositol monophosphatase IMPA1. Infect. Immun. 2013, 81, 4261-4270. [CrossRef]

198. Kennedy, G.M.; Hooley, G.C.; Champion, M.M.; Medie, F.M.; Champion, P.A.D. A novel ESX-1 locus reveals that surfaceassociated ESX-1 substrates mediate virulence in Mycobacterium marinum. J. Bacteriol. 2014, 196, 1877-1888. [CrossRef] [PubMed]

199. McLaughlin, B.; Chon, J.S.; MacGurn, J.A.; Carlsson, F.; Cheng, T.L.; Cox, J.S.; Brown, E.J. A mycobacterium ESX-1-secreted virulence factor with unique requirements for export. PLoS Pathog. 2007, 3, 105. [CrossRef]

200. Chen, J.M.; Zhang, M.; Rybniker, J.; Basterra, L.; Dhar, N.; Tischler, A.D.; Pojer, F.; Cole, S.T. Phenotypic profiling of Mycobacterium tuberculosis EspA point mutants reveals that blockage of ESAT-6 and CFP-10 secretion in vitro does not always correlate with attenuation of virulence. J. Bacteriol. 2013, 195, 5421-5430. [CrossRef] [PubMed]

201. Augenstreich, J.; Arbues, A.; Simeone, R.; Haanappel, E.; Wegener, A.; Sayes, F.; Le Chevalier, F.; Chalut, C.; Malaga, W.; Guilhot, C. ESX-1 and phthiocerol dimycocerosates of Mycobacterium tuberculosis act in concert to cause phagosomal rupture and host cell apoptosis. Cell. Microbiol. 2017, 19, e12726. [CrossRef] [PubMed]

202. Augenstreich, J.; Haanappel, E.; Ferré, G.; Czaplicki, G.; Jolibois, F.; Destainville, N.; Guilhot, C.; Milon, A.; Astarie-Dequeker, C.; Chavent, M. The conical shape of DIM lipids promotes Mycobacterium tuberculosis infection of macrophages. Proc. Natl. Acad. Sci. USA 2019, 116, 25649-25658. [CrossRef]

203. Osman, M.M.; Pagán, A.J.; Shanahan, J.K.; Ramakrishnan, L. Mycobacterium marinum phthiocerol dimycocerosates enhance macrophage phagosomal permeabilization and membrane damage. PLoS ONE 2020, 15, e233252. [CrossRef] [PubMed]

204. Raffetseder, J.; Iakobachvili, N.; Loitto, V.; Peters, P.J.; Lerm, M. Retention of EsxA in the capsule-like layer of Mycobacterium tuberculosis is associated with cytotoxicity and is counteracted by lung surfactant. Infect. Immun. 2019, 87, e00803-18. [CrossRef] [PubMed]

205. Karki, C.; Xian, Y.; Xie, Y.; Sun, S.; Lopez-Hernandez, A.E.; Juarez, B.; Wang, J.; Sun, J.; Li, L. A computational model of ESAT-6 complex in membrane. J. Theor. Comput. Chem. 2020, 19, 2040002. [CrossRef]

206. Meher, A.K.; Bal, N.C.; Chary, K.V.; Arora, A. Mycobacterium tuberculosis H37Rv ESAT-6-CFP-10 complex formation confers thermodynamic and biochemical stability. FEBS J. 2006, 273, 1445-1462. [CrossRef] [PubMed] 
207. Daleke, M.H.; Ummels, R.; Bawono, P.; Heringa, J.; Vandenbroucke-Grauls, C.M.; Luirink, J.; Bitter, W. General secretion signal for the mycobacterial type VII secretion pathway. Proc. Natl. Acad. Sci. USA 2012, 109, 11342-11347. [CrossRef] [PubMed]

208. Welin, A.; Björnsdottir, H.; Winther, M.; Christenson, K.; Oprea, T.; Karlsson, A.; Forsman, H.; Dahlgren, C.; Bylund, J. CFP-10 from Mycobacterium tuberculosis selectively activates human neutrophils through a pertussis toxin-sensitive chemotactic receptor. Infect. Immun. 2015, 83, 205-213. [CrossRef] 